\title{
Long-Term Effect of Rice-Wheat Cropping System on Cobalt in Relation to Manganese and Iron Content in Coarse Textured Calcareous Alluvial Soils
}

\author{
P N TAKKAR* \\ INSA Honorary Scientist, H-114, FF, Lajpat Nagar-1, New Delhi 110 024, India
}

(Received on 17 July 2014; Revised on 02 December 2014; Accepted on 11 March 2015)

\begin{abstract}
Deficiency of Cobalt (Co) in coarse textured soils leads to its deficiency in plants and animals affecting their productivity. As large area of coarse textured calcareous alluvial soils in the Indian Punjab has been brought under irrigated transplanted rice cultivation in rotation with wheat, submerged/reduced soil conditions tend to favor leaching of Co, leading to its deficiency. Objective of this study is to understand the changes with time, in transformation and leaching of Co in relation to that of $\mathrm{Mn}$ and $\mathrm{Fe}$, and also the possibility of Co deficiency when these fragile leaky soils are used to grow rice and wheat in an annual rotation on a long-term basis. Available (AA) (2.5\% acetic acid, pH 2.5 extractable) and oxide (OX) (0.2 M ammonium oxalate $+0.2 \mathrm{M}$ oxalic acid, $\mathrm{pH} 3.0$ extractable) fractions of $\mathrm{Co}, \mathrm{Mn}$ and Fe were estimated in 102 surface $(0-15 \mathrm{~cm})$ soils and 34 soil profiles under rice-wheat cultivation for 5 to 20 years in contiguous area of coarse textured calcareous alluvial soils in Ludhiana, Ferozepur, Faridkot and Kotkapura blocks in the Punjab. Available Co content ranged from deficient level of $0.01 \mathrm{mgkg}^{-1}$ to adequate level of $0.76 \mathrm{mg} \mathrm{kg}^{-1}$ with mean content of $0.26,0.28,0.32$ and $0.30 \mathrm{mg} \mathrm{kg}^{-1}$ and a corresponding 25, 42, 47 and 42\% Co deficient soils in Ludhiana, Ferozepur, Faridkot-Kotkapura and all the blocks, respectively. It followed the pattern of decrease in the content of OX-Co, -Mn and -Fe and increase in $\mathrm{CaCO}_{3}$ content and electrical conductivity in these districts. In these soils, OX-Co and OX-Mn coexist $\left(\mathrm{r}=0.38^{\mathrm{L}}\right.$ and $\mathrm{r}=$ $\left.0.628^{* * \mathrm{~F}}\right)$ in the oxide components but not with the $\mathrm{OX}-\mathrm{Fe}\left(\mathrm{r}=-0.437^{* \mathrm{~L}}\right.$ and $\left.\mathrm{r}=0.001^{\mathrm{F}}\right)$ fraction. The OX-Mn also regulates both available $\mathrm{Co}\left(\mathrm{AA}-\mathrm{Co}, \mathrm{r}=0.697^{*} * \mathrm{~L}\right)$ and AA-Mn $\left(\mathrm{r}=0.705^{* * \mathrm{~L}}\right)$. The $\mathrm{CaCO}_{3}$ content in the soil controlled both OX-Mn and OX-Co $\left(\mathrm{r}=0.282^{\mathrm{L}}\right.$ and $\left.\mathrm{r}=0.661^{*} * \mathrm{~L}\right)$ as well as, of AA-Mn and AA-Co $(\mathrm{r}=0.58 * * \mathrm{~L}$ and $0.52 * * \mathrm{~L}$, $0.43^{*} * \mathrm{~F}$ ) fractions. Thus, Co fractions are largely associated both with the soil Mn-oxide and $\mathrm{CaCO}_{3}$ constituents. But in the soils of Ferozepur block, organic carbon negatively regulates $\mathrm{OX}-\mathrm{Mn}\left(\mathrm{r}=-0.43^{* * \mathrm{~F}}\right), \mathrm{OX}-\mathrm{Co}\left(\mathrm{r}=-0.42^{* * \mathrm{~F}}\right)$ and positively both $\mathrm{OX}-\mathrm{Fe}\left(\mathrm{r}=0.35^{* * \mathrm{~F}}\right)$ and AA-Fe $\left(\mathrm{r}=0.59^{\mathrm{F}}\right)$ fractions. Long term effects of 5-20 years pertaining to alternate reduced and oxidized soil conditions under irrigated transplanted rice-wheat cultivation caused leaching losses of the oxides of Co, $\mathrm{Mn}$ and $\mathrm{Fe}$, as well as that of AA-Co, -Mn and -Fe fractions from the surface soil horizons to sub-surface horizons. (Superscript L,F and Fa denotes Ludhiana, Ferozepur and Faridkot-Kotkapura blocks, respectively)
\end{abstract}

Key Words: Soil Properties; Cobalt; Manganese and Iron Content; Available and Oxide Fractions; Leaching Losses; Anaerobic/Reduced Soil Conditions; Aerobic/Oxidized Soil Conditions; Cobalt Deficiency

\section{Introduction}

Cobalt (Co) is an essential element for animals, humans and leguminous plants. Since deficiency of Co in soil leads to its deficiency in plants and animals through the soil-plant-animal food chain, it affects both production and productivity of crops as well as health and productivity of animals. Animals and humans require $\mathrm{Co}$ in the form of Vitamin $\mathrm{B}_{12}$. In animals, its deficiency is noticed mainly in ruminants 
grazed or fed on Co-deficient pastures, feed or diet, as the rumen bacteria required $\mathrm{Co}$ for the production of vitamin $B_{12}$ of which it is the integral constituent. Non-ruminants require it in the form of $\mathrm{B}_{12}$. Essential role of $\mathrm{Co}$ in the functioning of Rhizobium-alfa (Medicago sativa $\mathrm{L}$.) symbiosis system in $\mathrm{N}_{2}$-fixation was established by Reisenauer (1960). Delwiche et al., (1961) showed that the absence of either Co or Rhizobium inoculum caused severe $\mathrm{N}$ deficiency and addition of Co increased the yield of legumes threefold during the period of $\mathrm{N}$ stress. The production of the vitamin $B_{12}$ is seriously hampered in symbiotic bacteria responsible for the fixation on $\mathrm{N}_{2}$ in legumes when Co supply is inadequate, consequently resulting in less $\mathrm{N}_{2}$-fixation and manifestation of $\mathrm{N}$-deficiency (Gladstones et al., 1977). Whereas nodule bacteroid content and leghaemglobin content were linearly related to cobalamin ( $\mathrm{B}_{12}$ vitamin) content suggesting their role in $\mathrm{N}_{2}$ fixation in legume nodules for a noncobalamin form of Co (Dilworth et al., 1979).

The total Co content in the Earth's crust is 25 $\mathrm{mgkg}^{-1}$ and in the world and Indian soils it varies widely from traces to $277 \mathrm{mg} \mathrm{kg}^{-1}$ and depends largely on the parent rock and climate of the region. Several studies indicate a strong relationship between the total content of $\mathrm{Co}$ and $\mathrm{Mn}$ and/or Fe because Co and $\mathrm{Mn}$ have similar chemical properties (Fleming, 1983; Baize and Sterckeman, 2001; Schuiling, et al., 2003; Cappuyns and Mallaerts, 2014). However the available Co content ranged from 0.06 to 2.1 mgkg $^{-1}$ (Swaine, 1955; Mitchell, 1960; Randhawa and Kanwar, 1964; Kanwar and Randhawa, 1974; Aubert and Pinta, 1977; Ure and Berrow, 1982). In Co deficient soils the available (acetic acid extractable) Co content is generally less than 0.25 $\mathrm{mg} \mathrm{kg}^{-1}$ (Mitchell, 1945; Stewart, 1953). The amount of Co extracted with acetic acid and EDTA was derived principally from easily reducible Mn-oxides and was highly dependent on the length of extraction period and on the temperature. The available Co content depends on several factors such as texture, $\mathrm{pH}, \mathrm{CaCO}_{3}, \mathrm{Mn}$ and $\mathrm{Fe}$ oxides, organic matter content, drainage status and processes under different soil-crop management systems and practices. In the alluvial surface soils of Kapurthala and Jalandhar districts of Punjab, the available Co $(2.5 \%$ acetic acid extractable) content ranged from 0.20 to 0.50 and 0.11 to $1.17 \mathrm{mg} \mathrm{kg}^{-1}$ respectively and nearly 31 and $12 \%$ soils respectively were categorized as deficient in Co. Also, significant negative relationship between $\mathrm{Co}$ and $\mathrm{pH}$ in the soils of Jalandhar district was recorded (Bansal et al., 1991; Singh et al., 1980). Generally, coarse-textured (sandy) soils contain lesser amount of available as well as total Co than finetextured (clay-like) soils. Nevertheless, the activity of $\mathrm{Mn}$ oxides and the reactions that alter $\mathrm{Mn}$ in soils largely influence the solubility and availability of Co (Uren, 2013).

In soils, $\mathrm{MnO}_{2}$ minerals often occur in exceedingly finely divided forms which possess very high absorptive capacity and their crystal structures are such that they readily accommodate Co ions. Thus, in high Mn soils the availability of Co is expected to be restricted despite the soils are high in Co content. Recent study of Cappuyns and Mallaerts (2014) confirmed earlier work (Taylor and McKenzie, 1966; McKenzie, 1967a; Taylor, 1968; Bibak, 1994; Li et al., 1999, 2001a, 2001b, 2004; Faucon et al., 2009; Tashakor et al., 2011) that Mn oxides properties are important in the sequestration, scavenging, fixing or adsorption of Co in soils. Several researchers have shown that Co is strongly absorbed by $\mathrm{Mn}$ - and Feoxides and is not readily desorbed (Taylor and McKenzie, 1966; McKenzie, 1975; McLaren et al., 1986a, 1986b). As ionic radii of $\mathrm{Co}^{3+}$ and $\mathrm{Mn}^{4+}$ are in close agreement, some Co substitution for $\mathrm{Mn}^{4+}$ ions occur in edge-shared $\left[\mathrm{MnO}_{6}\right]$ octahedral in $\mathrm{Mn}$ (IV) mineral structures. On the surface of these minerals hydrated $\mathrm{Co}$ ions $\left(\mathrm{CoH}_{2} \mathrm{O}\right)_{6}{ }^{2+}$ are initially adsorbed in the vicinity of key vacancies found in the chains or sheets. As a consequence, fixation of Co take place, due to oxidation of adsorbed $\mathrm{Co}^{2+}$ ions by $\mathrm{Mn}^{4+}$ and replacement of the displaced $\mathrm{Mn}$ by lowspin $\mathrm{Co}^{3+}$ ions in the $\left[\mathrm{MnO}_{6}\right]$ octahedra or vacancies (Burns, 1976). The study of Murray and Dillard (1979) also revealed strong evidence that Co (II) gets oxidized to Co (III). Wendling et al. (2007) also observed nearly complete oxidation of added $\mathrm{Co}$ (II) to $\mathrm{Co}$ (III) on the surfaces of soils bearing high concentrations of $\mathrm{Mn}, \mathrm{Fe}$ and $\mathrm{Al}$ oxides. Soil is a combination of several reactive fractions, that have the ability to interact physically and chemically with 
Co and other heavy metals, which consequently changes their existence form in the soil (Tashakor et al., 2011). The weathering of Co-bearing Fe and Mn minerals is faster under submerged, water-logged and impeded drainage conditions and therefore expected to change their existence forms. Under reduced or anaerobic conditions of restricted drainage, the most marked effect on the contents of extractable Co was the increase in its mobilization and very high extractable Co contents in the gleyed horizons (Swaine and Mitchell, 1960).

Conventionally, irrigated transplanted rice was not grown on coarse textured soils because of their high permeability. These soils are considered as nontraditional rice soils. However, these soils in the Indian Punjab are now increasingly being brought under transplanted rice cultivation. The resulting submerged/reduced soil conditions under rice result in different chemical, biological and physical processes than the one under aerobic/oxidized soil conditions. These changes in turn influence the chemistry and availability of different Co fractions and alter the Co deficiency problems in these soils. Punjab (In India) was traditionally not a rice growing region but has become so and has made incredible progress in rice productivity during the past 48 years. In 1965, rice was grown largely in traditional rice soils, clayey loam to loam having low to very low permeability. These soils occupied an area of only 0.29 Mha with production of $0.29 \mathrm{Mt}$ and productivity of $1.0 \mathrm{tha}^{-1}$. The area under rice increased at the rate of 0.1-Mha year ${ }^{-1}$; from 0.39 Mha in 1970-71 to 1.18 in 1980-81, 2.02 in 1990-91, 2.61 in 2000-01 and 2.64 Mha in 2005-06, and it has stabilized around 2.82 Mha. This resulted in an increase of 9-fold area under rice cultivation. Now rice-wheat became the major cropping system in the state. Total production of rice ranged from 10.54 to $11.43 \mathrm{~m}$ tons and productivity from 3.74 to 4.02 tha $^{-1}$ from an area of 2.8 to 2.82 Mha during the years of 2008-09 to 201112. This development happened by bringing under rice cultivation the non-traditional coarse textured highly permeable loamy sand soils as well moderately permeable sandy loam soils, which was regarded otherwise not suitable for rice cultivation. This dramatic change occurred because the farmers got higher rice productivity and far better economic benefits as compared to other upland crops, such as maize, groundnut, cotton, pulses. Besides, the farmers have easy and cheap access to ground water for irrigation at their command, which, with time made it possible to raise rice on these nontraditional permeable soils successful on a large scale.

The rice-wheat cropping system (RWCS) has brought a major change in the ecology of this region from upland cropping systems of maize-wheat, cotton-wheat, and groundnut-wheat grown largely under aerobic/oxidized soil conditions to irrigated transplanted rice-wheat cultivation. These alternate seasonal conditions of soil reduction and oxidation have triggered different chemical, biological and physical processes in such soils that caused emergence of, $\mathrm{Zn}, \mathrm{Mn}, \mathrm{K}$ and $\mathrm{S}$ deficiencies and toxicity of Se in the rice-based cropping systems (Takkar, 1996; Takkar and Dhillon, 1984; Takkar and Randhawa, 1990; Dhillon and Dhillon, 2003). During the initial periods of rice introduction in these "leaky" coarse textured soils, farmers encountered difficulties in making the water to stand in the field for rice cultivation and as a consequence of this reduction of Fe did not occur that led to severe Fe-deficiency in rice and even failure of rice crop (Takkar and Nayyar, 1979). But after 2-3 cycles of RWCS, water starts staying in these soils. The resulting processes of soil reduction led to sufficient mobilization of $\mathrm{Fe}^{2+}, \mathrm{Mn}^{2+}$ and created conditions favourable to meet the $\mathrm{Fe}$ and other requirements of rice. But over a period of 6 to 8 years of R-W cultivation in these soils, leaching of Mn occurred from upper active root-zone to lower horizons that led to the decrease in available Mn content in soil horizon of active root-zone and consequently resulted in field-scale Mn-deficiency in wheat which was noticed here for the first time (Takkar and Nayyar, 1981; Takkar et al., 1986). Now its deficiency has extensively increased and become a perpetual problem in limiting wheat production and productivity. An analogy to that of emergence of Mndeficiency due to its leaching losses, the deficiency of Co or its low levels is not ruled out in these fragile coarse textured permeable soils brought under rice cultivation. As Co is largely associated with $\mathrm{Mn}$ and Fe hydroxides/oxides and upon their weathering and 
reduction, Co is likely to be released and subject to leaching along with $\mathrm{Mn}$ and $\mathrm{Fe}$ especially under prolonged periods of alternate anaerobic/reduced and aerobic/oxidized conditions of irrigated RWCS. If it happens often, Co deficiency may emerge on a wide scale and would impede crop and animal productivity. But the knowledge on the transformation, leaching and deficiency of Co in relation to $\mathrm{Mn}$ and $\mathrm{Fe}$ content is lacking in these soils under different periods of irrigated rice-wheat cultivation. The objective of the present study is to assess the long term effects of alternate reduced and oxidized soil conditions under irrigated RWCS on Co in relation to concurrent changes in $\mathrm{Mn}$ and $\mathrm{Fe}$ content and the possibility of occurrence of Co deficiency in coarse textured calcareous alluvial soils.

\section{Materials and Methods}

\section{Study Area}

The study area comprised the soils of Ludhiana, Ferozepur, Faridkot and Kotkapura districts of Punjab under rice-wheat cropping systems (RWCS) for 5 to 20 or more years. Rice-wheat rotation is the major cropping system in the study area as well in the state. The Ludhiana district is bounded between north latitude $30^{\circ} 33^{\prime}$ and $31^{\circ} 01^{\prime}$ and east longitude $75^{\circ}$ $25^{\prime}$ and $76^{\circ} 27^{\prime}$. The district has 12 development blocks and Ludhiana block-1 is the one selected for this study. The soils of the investigated block belong to the Inceptisol order and are largely permeable, coarse in texture that ranges largely from loamy-sandy to sandy-loam and slightly alkaline in reaction with $\mathrm{pH}$ range of 7.8-8.5. The Ferozepur district is located between $29^{\circ} 56^{\prime} 47^{\prime \prime}$ and $31^{\circ} 0^{\prime} 7^{\prime \prime}$ north latitudes and $72^{\circ} 52^{\prime} 54^{\prime \prime}$ and $75^{\circ} 01^{\prime} 11^{\prime \prime}$ east longitudes and comprises of 10 blocks of which Ferozepur block is the one selected for this study. The soil of this area belongs to Entisol-Inceptisol order. Soil-type varies from loamy sand to sandy loam and some are medium to even heavy textured clay. The Faridkot district is located in the south-western parts of Punjab state and is confined within northern latitudes of $29^{\circ} 54^{\prime} 00^{\prime \prime}$ to $34^{\circ} 4^{\prime} 00^{\prime \prime}$ and the eastern longitudes of $74^{\circ} 15^{\prime} 00^{\prime \prime}$ to $75^{\circ} 25^{\prime} 00^{\prime \prime}$. The Faridkot and Kotkapura blocks were selected for the study. By and large, soils of
Faridkotdistricts belongs to Inceptisol and Entisol orders and are coarse textured-largely loamy sand, followed by sandy loam and have low fertility and productivity. More than $99 \%$ of the area is irrigated and the main source of irrigation is canals supplemented by tube wells.

\section{Soil Sampling}

The soil samples were collected from 34 soil profiles at a depth of $0-15,15-30,30-45,45-60 \mathrm{~cm}$ and 102 surface soil samples $(0-15 \mathrm{~cm}$ depth) from the four blocks of three districts of Punjab. The soil samples were selected to be truly representative of their region as well as contiguous area of coarse textured soils, largely loamy sand to sandy loam, brought under ricewheat cropping system (RWCS) for about 5, 10, 15 and 20 or more years as shown in Table 1. All the soil samples were air-dried, ground gently in a wooden pestle and mortar to pass through $2 \mathrm{~mm}$ screen and stored in polythene bags for analysis.

\section{Soil Analysis}

Soil samples were analysed for $\mathrm{pH}$ (1: 2 Soil water) and EC (1:2 supernatant) following standard procedures. Organic carbon (OC) was determined by the method of Walkley (1947) and calcium carbonate $\left(\mathrm{CaCO}_{3}\right)$ by the methods of Piper (1950). The samples were analyzed for various fractions of cobalt, manganese and iron adopting the following methods.

\section{Acetic Acid Extractable Co (available), Mn and Fe}

Reddy and Mehta (1961) showed that 2.5\% acetic acid method of Mitchell (1945) gave better relationship with Co uptake by crops than the other methods. Therefore, $2.5 \%$ acetic acid $(\mathrm{pH} 2.5)$ method was used to extract available Co from soils; also from the same extracts $\mathrm{Mn}$ and Fe were estimated. To find out the best ratio and time of shaking the soil with acetic acid solution for the estimation of available Co, $10 \mathrm{~g}$ soil from Ludhiana block was extracted with 1:1. 1:1.25, 1:1.5, 1:1.75, 1:20 and 1:2.5 soil:acetic acid solution ratios. The data in Table 2 show that soil:solution ratio of 1:2.5 and shaking time of 24 hours extracted the maximum and almost steady amount of Co and was adopted in 
Table 1: Details of soil sampling sites and of profiles and surface samples

\begin{tabular}{|c|c|c|c|}
\hline Villages & $\begin{array}{l}\text { No. of } \\
\text { profiles }\end{array}$ & Number of profiles with years under RWCS & $\begin{array}{c}\text { No. of } \\
\text { surface samples }\end{array}$ \\
\hline \multicolumn{4}{|c|}{ Ludhiana Block of Ludhiana District } \\
\hline Bhatta Dua & 4 & $2=10$ yrs., $2=20$ yrs. & 12 \\
\hline \multicolumn{4}{|c|}{ Ferozepur Block of Ferozpur District } \\
\hline Malewal Kadeem & 3 & $1=5$ yrs., $1=10$ yrs., $1=20$ yrs. & 6 \\
\hline Piareana & 3 & $1=5$ yrs., $2=10$ yrs. & 15 \\
\hline Ratta Khera & 3 & $1=5$ yrs., $1=10$ yrs., $1=>10$ yrs. & 13 \\
\hline NurpurSethan & 6 & $2=5$ yrs., $2=10$ yrs., $2=>10$ yrs. & 20 \\
\hline \multicolumn{4}{|c|}{ Faridkot* and Kotkapura\# Blocks of Faridkot District } \\
\hline Beelewala* & 6 & $2=5$ yrs., $2=10$ yrs., $2=15 \mathrm{yrs}$ & 10 \\
\hline Golewal* & 3 & $1=5$ yrs., $1=10$ yrs., $1=15 \mathrm{yrs}$ & 8 \\
\hline Dod\# & 6 & $2=5$ yrs., $2=10$ yrs., $2=15 \mathrm{yrs}$ & 18 \\
\hline \multirow[t]{2}{*}{ Total } & 34 & & \\
\hline & & & 102 \\
\hline
\end{tabular}

Table 2: Acetic acid (2.5\%) extractable Co in sandy soils of Village Bhatta Dhua of Ludhiana block as influenced by soil: solution ratio and period of extraction

\begin{tabular}{lccccc}
\hline Soil: Solution & \multicolumn{5}{c}{ Period of extraction/shaking } \\
\cline { 2 - 6 } Ratio & $1 \mathrm{hr}$ & $2 \mathrm{hr}$ & $4 \mathrm{hr}$ & $6 \mathrm{hr}$ & $24 \mathrm{hr}$ \\
\hline $1: 1$ & 0.165 & 0.165 & 0.150 & 0.156 & 0.175 \\
$1: 1$ & 0.175 & 0.175 & 0.160 & 0.155 & 0.175 \\
$1: 1.25$ & 0.193 & 0.193 & 0.175 & - & 0.206 \\
$1: 1.25$ & 0.193 & 0.193 & 0.175 & 0.194 & 0.190 \\
$1: 1.5$ & 0.230 & 0.230 & 0.225 & 0.234 & 0.218 \\
$1: 1.5$ & 0.230 & 0.230 & 0.210 & 0.203 & 0.248 \\
$1: 1.75$ & 0.254 & 0.254 & 0.245 & 0.236 & 0.248 \\
$1: 1.75$ & 0.254 & - & 0.228 & 0.236 & 0.254 \\
$1: 2$ & 0.250 & 0.270 & 0.260 & 0.250 & 0.310 \\
$1: 2$ & 0.270 & 0.290 & 0.240 & 0.270 & 0.270 \\
$1: 2.5$ & 0.287 & 0.313 & 0.275 & 0.288 & 0.313 \\
$1: 2.5$ & 0.313 & 0.313 & 0.275 & 0.288 & 0.313 \\
\hline & & & & &
\end{tabular}

the present study for the estimation of available Co. The concentration of Co, Mn and Fe in the extracts was estimated with atomic absorption spectrophotometer. Throughout the manuscript acetic acid extractable $\mathrm{Co}, \mathrm{Mn}$ and $\mathrm{Fe}$ are designated as AACo, AA-Mn and AA-Fe respectively.

\section{Oxide Bound Co, Mn and Fe}

The oxide bound Co, Mn and Fe was determined by extracting the soil with acid ammonium oxalate $(0.2$ $\mathrm{M}$ ammonium oxalate and 0.2 M oxalic acid, $\mathrm{pH} 3.3$ ) reagent. These elements in the extracts were estimated with atomic absorption spectrophotometer (McKeague and Day, 1966). The oxide bound Co, $\mathrm{Mn}$, and $\mathrm{Fe}$ is designated as $\mathrm{OX}-\mathrm{Co}, \mathrm{OX}-\mathrm{Mn}$ and $\mathrm{OX}$ Fe respectively.

\section{Results and Discussion}

The soils of investigated blocks of three districts vary markedly in the degree of calcareousness $\left(\mathrm{CaCO}_{3}\right)$ and salt content (EC) that increased in the order of Ludhiana, Ferozpur and Faridkot region (Table 3 and 4). Thus, results are reported and discussed block-wise. 


\section{Ludhiana Block}

The range and mean values of $\mathrm{pH}, \mathrm{EC}, \mathrm{CaCO}_{3}$ and OC content in the profiles and surface soil samples are shown in Table 3 and 4 . The $\mathrm{pH}$ in the surface and profile soil samples of the Ludhiana block ranged between 7.77 and 8.98 and the mean value 8.62 in the profile soils was higher as compared to 8.34 in the surface samples. The histograms in Fig. 1 show that $\mathrm{pH}$ increased appreciably with soil depth as well as with time of cultivation of RWCS. The salt content (EC) in these soils varied from 0.12 to $0.86-\mathrm{dSm}^{-1}$ and its mean content of $0.27-\mathrm{dSm}^{-1}$ was markedly higher (1.7 times) in the surface soils than $0.16-\mathrm{dSm}^{-}$ ${ }^{1}$ in the profiles.This has resulted from the addition of salt through irrigation with ground water as well as addition of fertilizers. In contrast, the salt content decreased with soil depth (Fig. 1). The negative and highly significant relation of EC with soil $\mathrm{pH}(\mathrm{r}=-$ $0.72 * *)$ suggests that salt concentration regulated $\mathrm{pH}$ in these soils (Table 5). The $\mathrm{CaCO}_{3}$ content both in surface and profile samples ranged between 1.0 and $6.5 \%$ with a mean content of $2.8 \%$ in profiles and $2.1 \%$ in the surface soils. The $\mathrm{CaCO}_{3}$ content increased with soil depth but decreased with time of R-W cultivation (Fig. 1), demonstrating that these soils are calcareous. The OC content in both the surface and profile samples varied from low $(0.10 \%)$ to medium content $(0.75 \%)$ and was appreciably higher $0.448 \%$ in the surface soils than $0.28 \%$ in the profiles; however, it conspicuously decreased with soil depth (Fig. 1) as a result of more accumulation of root biomass in the surface than in the subsurface

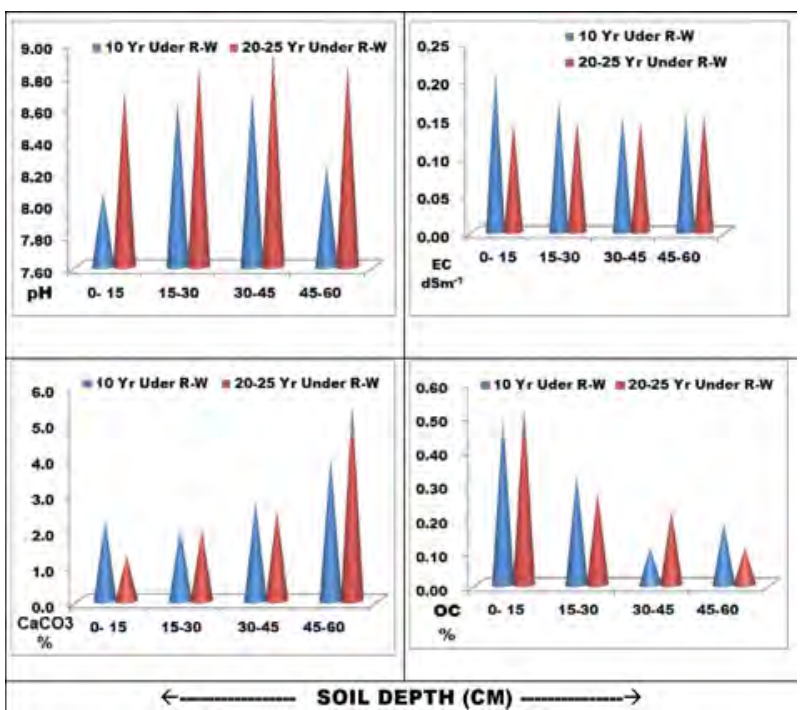

Fig. 1: Changes in soil pH, EC, $\mathrm{OC}$ and $\mathrm{CaCO3}$ content with periods of $R-W$ cultivation in soil profiles of Ludhiana block

layers with period of cropping.

Available Co: The available Co content in the surface and profiles samples ranged from 0.10 to 0.54 $\mathrm{mg} \mathrm{kg}-1$ and 0.18 to $0.60 \mathrm{mg} \mathrm{kg}^{-1}$ with a mean content 0.32 and $0.34 \mathrm{mg} \mathrm{kg}^{-1}$, respectively. Histograms in Fig. 2 show that AA-Co content generally decreased with time of rice-wheat (R-W) cultivation but increased with soil depth. The decrease in AA-Co with periods of rice-wheat (R-W) cultivation has resulted partially due to its removal by crops over the years especially from the upper soil layers. The increase in Co content with soil depth has resulted largely due to leaching of Co down the profile under reduced conditions of rice culture in these permeable

Table 3: Range and mean values of soil properties and acetic acid (AA) and oxalic acid (OX) extractable Co, Mn and Fe in the surface soil samples of Ludhiana,Ferozepur and Faridkot districts

\begin{tabular}{|c|c|c|c|c|c|c|c|c|c|c|c|}
\hline District & Category & $\begin{array}{c}\mathrm{pH} \\
1: 2 \text { Soil: } \mathrm{H}_{2} \mathrm{O}\end{array}$ & $\begin{array}{c}\mathrm{EC} \\
\mathrm{dSm}^{-1}\end{array}$ & $\begin{array}{l}\mathrm{OC} \\
(\%)\end{array}$ & $\mathrm{CaCO}_{3}$ & AA-Co & $\begin{array}{l}\text { AA-Mn } \\
\mathrm{mg} \mathrm{kg}^{-1}\end{array}$ & AA-Fe & OX-Co & $\begin{array}{l}\text { OX-Mn } \\
\mathrm{mg} \mathrm{kg}^{-1}\end{array}$ & $\mathrm{OX}-\mathrm{Fe}$ \\
\hline \multirow[t]{2}{*}{ Ludhiana } & Range & $7.80-8.75$ & $0.12-0.86$ & $0.142-0.746$ & $1.0-4.5$ & $0.10-0.54$ & $5.90-39.6$ & $0.20-2.84$ & $0.72-1.39$ & $11.2-64.4$ & $194-424$ \\
\hline & Mean & 8.34 & 0.27 & 0.448 & 2.13 & 0.32 & 16.90 & 1.40 & 0.92 & 36.7 & 315.5 \\
\hline \multirow[t]{2}{*}{ Ferozepur } & Range & $7.02-8.76$ & $0.129-1.07$ & $0.12-0.87$ & $1.0-9.2$ & $0.04-0.87$ & $1.46-41.0$ & $0.28-12.22$ & $0.02-1.10$ & $0.4-90.9$ & $24-401$ \\
\hline & Mean & 8.12 & 0.45 & 0.456 & 3.0 & 0.28 & 23.14 & 1.61 & 0.32 & 14.9 & 176.4 \\
\hline \multirow[t]{2}{*}{ Faridkot } & Range & $7.35-9.43$ & $0.24-3.9$ & $0.12-0.60$ & $1.0-5.5$ & $0.12-0.50$ & $0.30-24.0$ & $0.2-3.40$ & $0.16-1.40$ & & \\
\hline & Mean & 8.33 & 0.80 & 0.34 & 4.11 & 0.26 & 9.74 & 0.90 & 0.40 & & \\
\hline \multirow[t]{2}{*}{ All } & Range & $7.02-9.43$ & $0.12-3.9$ & $0.12-0.750$ & $1.0-9.2$ & $0.04-0.54$ & $0.30-41.0$ & $0.20-12.22$ & $0.02-1.40$ & 0.4-90.9 & $24-424$ \\
\hline & Mean & 8.26 & 0.51 & 0.42 & 3.08 & 0.29 & 16.59 & 1.30 & 0.55 & 25.79 & 245.93 \\
\hline
\end{tabular}




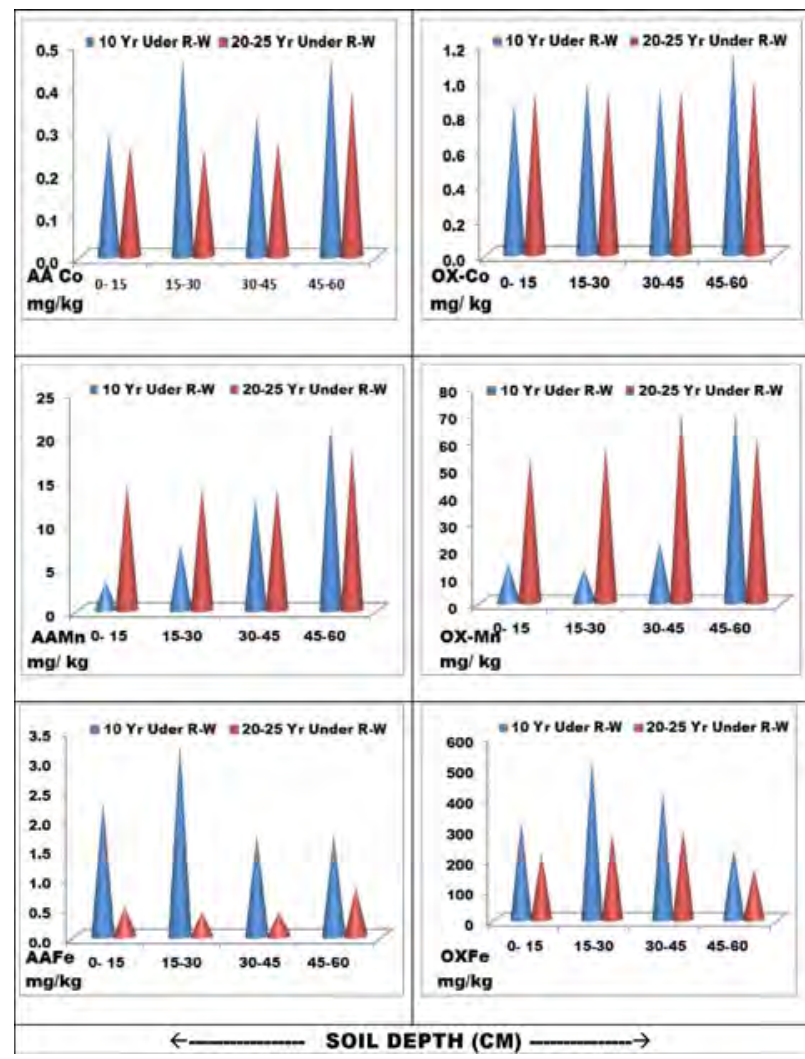

Fig. 2: Changes in acetic acid (AA) extractable and oxide (OX) fractions of Co, Mn and Fe content in soil profiles under different periods of $\mathrm{R}-\mathrm{W}$ cultivation in Ludhiana block (Average values of 4 profiles)

soils. Cobaltous (Il) ion is a dominant species in nature and forms complexes with naturally occurring ligands and in its complexes state it is often unstable so get readily oxidized, while cobaltic Co (III) complexes generally form stable compounds. These complexes may be neutral or negatively charged and are thus capable of migration or leaching (Smith and Martell, 1976, 1977). Further, it has been shown that poor soil drainage conditions cause an increase in Co, a phenomenon attributed to the reduction and dissolution of $\mathrm{Mn}$ and Fe oxides and concurrent release of the associated Co (Hill et al., 1953; Mitchell et al., 1957; Adams and Honeysett, 1964; Berrow et al., 1983; Cornu et al., 2009). The released Co becomes susceptible to leaching in coarse textured soils under submerged state. A decrease in soil redox potential occurs when soil is flooded or submerged, as being practiced under the investigated irrigated rice cultivation. This results in the reduction of $\mathrm{Mn}$ and $\mathrm{Fe}$ oxides and the release of adsorbed Co from these oxides. Further, a decrease in soil pH upon submergence of the alkaline soils, as the one under investigation, causes solubilization of precipitated Co, desorption of Co and an increase in Co mobility (Smith and Carson, 1981) especially in coarse texture investigated soils. In addition, adsorbed Co in mobile colloids fraction would enhance its mobility. Typically, Co is more mobile than other metals, such as $\mathrm{Pb}, \mathrm{Ni}, \mathrm{Cr}$ and $\mathrm{Zn}$ in soil (Mahara and Kudo, 1981; Smith and Carson, 1981; Baes and Sharp, 1983; King 1988; Tashakor et al., 2011). Soil mobility of Co has been reported to be inversely related to the strength of adsorption by soil constituents (Kim et al., 2006), which is expected to be lesser in the investigated coarse textured sandy soils than in fine textured clayey soils, hence the investigated soils are more vulnerable to mobility of Co. Also Co has been found to leach from municipal and low-level radioactive

Table 4: Range and mean values of soil properties and acetic acid (AA) and oxalic acid (OX) extractable Co, Mn and Fe in the soil profile of Ludhiana, Ferozepur and Faridkot-Kotkapura blocks

\begin{tabular}{|c|c|c|c|c|c|c|c|c|c|c|c|}
\hline District & $\begin{array}{r}\text { Category } \\
1\end{array}$ & $\begin{array}{l}\mathrm{y} \quad \mathrm{pH} \\
1: 2 \text { Soil: } \mathrm{H}_{2} \mathrm{O}\end{array}$ & $\begin{array}{c}\mathrm{EC} \\
\mathrm{dSm}^{-1}\end{array}$ & $\begin{array}{l}\mathrm{OC} \\
(\%)\end{array}$ & $\mathrm{CaCO}_{3}$ & AA-Co & $\begin{array}{l}\text { AA-Mn } \\
\mathrm{mg} \mathrm{kg}^{-1}\end{array}$ & AA-Fe & $\mathrm{OX}-\mathrm{Co}$ & $\begin{array}{l}\text { OX-Mn } \\
\mathrm{mg} \mathrm{kg}^{-1}\end{array}$ & $\mathrm{OX}-\mathrm{Fe}$ \\
\hline Ludhiana & $\begin{array}{l}\text { Range } \\
\text { Mean }\end{array}$ & $\begin{array}{c}7.77-8.98 \\
8.62\end{array}$ & $\begin{array}{c}0.13-0.26 \\
0.16\end{array}$ & $\begin{array}{c}0.072-0.746 \\
0.280\end{array}$ & $\begin{array}{c}1.0-6.5 \\
2.8\end{array}$ & $\begin{array}{c}0.18-0.6 \\
0.34\end{array}$ & $\begin{array}{c}5.90-26.10 \\
13.96\end{array}$ & $\begin{array}{c}0.30-3.52 \\
1.53\end{array}$ & $\begin{array}{c}0.82-1.34 \\
0.98\end{array}$ & $\begin{array}{c}11.2-87.0 \\
44.8\end{array}$ & $\begin{array}{c}140-543 \\
336\end{array}$ \\
\hline Ferozepur & $\begin{array}{l}\text { Range } \\
\text { Mean }\end{array}$ & $\begin{array}{l}7.20-9.0 \\
8.26\end{array}$ & $\begin{array}{c}0.129-1.07 \\
0.410\end{array}$ & $\begin{array}{c}0.085-0.75 \\
0.26\end{array}$ & $\begin{array}{c}1.0-8.0 \\
3.2\end{array}$ & $\begin{array}{c}0.01-0.76 \\
0.30\end{array}$ & $\begin{array}{c}8.5-41.0 \\
21.24\end{array}$ & $\begin{array}{c}0.12-3.74 \\
0.86\end{array}$ & $\begin{array}{c}0.14-1.124 \\
0.47\end{array}$ & $\begin{array}{c}4.3-83.9 \\
26.1\end{array}$ & $\begin{array}{c}7-401 \\
141\end{array}$ \\
\hline $\begin{array}{l}\text { Faridkot- } \\
\text { Kotkapua }\end{array}$ & $\begin{array}{l}\text { Range } \\
\text { Mean }\end{array}$ & $\begin{array}{c}7.43-9.68 \\
8.28\end{array}$ & $\begin{array}{c}0.25-0.82 \\
0.51\end{array}$ & $\begin{array}{c}0.10-0.60 \\
0.27\end{array}$ & $\begin{array}{c}2.0-9.5 \\
4.59\end{array}$ & $\begin{array}{c}0.02-0.54 \\
0.25\end{array}$ & $\begin{array}{c}1.9-22.8 \\
7.80\end{array}$ & $\begin{array}{c}0.01-1.86 \\
0.63\end{array}$ & $\begin{array}{c}0.14-1.52 \\
0.48\end{array}$ & - & - \\
\hline All Blocks & $\begin{array}{l}\text { Range } \\
\text { Mean }\end{array}$ & $\begin{array}{c}7.2-9.68 \\
8.39\end{array}$ & $\begin{array}{c}0.129-1.07 \\
0.361\end{array}$ & $\begin{array}{c}0.072-0.75 \\
0.270\end{array}$ & $\begin{array}{c}1.0-9.5 \\
3.52\end{array}$ & $\begin{array}{c}0.01-0.76 \\
0.30\end{array}$ & $\begin{array}{c}0.58-41.0 \\
14.33\end{array}$ & $\begin{array}{c}0.01-3.74 \\
1.01\end{array}$ & $\begin{array}{c}0.14-1.52 \\
0.64\end{array}$ & $\begin{array}{c}4.3-87.0 \\
35.4\end{array}$ & $\begin{array}{c}7.0-543 \\
238\end{array}$ \\
\hline
\end{tabular}


waste sites (Cyr et al., 1987; Friedman and Kelmers, 1988). Thus, it is expected that leaching of Co has taken place especially in the investigated permeable sandy soils under submerged/reduced condition of rice culture.

AA-Mn and AA-Fe: The data in Tables 3 and 4 show that AA-Mn fraction in the surface and profile samples varied from 5.9 to $39.6 \mathrm{mg} \mathrm{kg}^{-1}$ and that of AA-Fe from 0.20 to $3.52 \mathrm{mg} \mathrm{kg}^{-1}$. The respective mean content of AA-Mn and AA-Fe was 16.9 and $1.4 \mathrm{mg} \mathrm{kg}^{-1}$ in the surface soils and 13.96 and 1.53 $\mathrm{mg} \mathrm{kg}^{-1}$ in the profiles. Nevertheless, AA-Mn markedly increased and AA-Fe decreased with time of $\mathrm{R}-\mathrm{W}$ cultivation. This pattern was consistent under 10-years period of R-W cultivation but was different under 20-25 years period where AA-Mn slightly decreased up to $45 \mathrm{~cm}$ depth (Fig. 2). By and large, similar pattern of distribution of AA-Co and AA-Mn in these profiles and a positive and significant relation of both these fractions with $\mathrm{CaCO}_{3}, \mathrm{r}=0.52 * *$ and $\mathrm{r}$ $=0.58 * *$ respectively, suggest their co-existence as carbonates. Under alkaline conditions or in calcareous soils both $\mathrm{Mn}^{2+}$ and $\mathrm{Co}^{2+}$ is immobilized by forming insoluble carbonates. The results thus indicate that soluble Co and Mn concentrations could be reasonably well predicted from soil carbonate contents and the respective AA-extractable metal concentrations.

It is interesting to note that the relative proportions of $\mathrm{Co}, \mathrm{Mn}$ and $\mathrm{Fe}$ extracted by acetic acid were significantly correlated for both Co x Mn $\left(\mathrm{r}=0.54^{* *}\right)$ and $\mathrm{Co} \times \mathrm{Fe}\left(\mathrm{r}=0.58^{* *}\right)$ indicating a strong relationship between these elements (Table 5). In soils, $\mathrm{Co}, \mathrm{Mn}$ and $\mathrm{Fe}$ appear to be strongly associated due to their close geochemical relationship (Li et al., 2001a, 2001b; Tashakor et al., 2011). These relationships suggest that acetic acid solution $(\mathrm{pH} 2.5)$ mobilizes Co by dissolving the $\mathrm{CaCO}_{3}$ as well as, desorbing the $\mathrm{Co}$ associated with $\mathrm{CaCO}_{3}$ and oxides of Mn and Fe. The study of Han et al. (2002) lends support to these findings. They observed that during the long-term saturated incubation, Co in six arid soils was redistributed among the solid phases mainly from the $\mathrm{Mn}$ oxide bound, and to some extent, $\mathrm{Fe}$ oxide bound and organic matter bound fractions into the carbonate bound fraction. Also during saturated incubation, significant correlations were found between the concentrations of $\mathrm{Co}$ and $\mathrm{Mn}$ in the $\mathrm{Mn}$ oxide bound, $\mathrm{Fe}$ oxide bound and carbonate bound fractions. Furthermore, Li (2000) observed strong correlations of Co with $\mathrm{Mn}$ in the New Zealand soils. Also, a significant proportion of soil Co was associated with soil $\mathrm{Mn}$ and showed similarities in its relationships with soil $\mathrm{pH}$.

The $\mathrm{pH}$ was found to be an important factor affecting the concentration of $\mathrm{Co}, \mathrm{Mn}$ and $\mathrm{Fe}$, which decreased with increasing soil $\mathrm{pH}$. The negative and significant relation of $\mathrm{pH}$ with AA-Co $\left(\mathrm{r}=-0.44^{*}\right)$ and AA-Fe $\left(r=-0.48^{*}\right)$ demonstrate that available Co content and AA-Fe could be practically well predicted from the soil $\mathrm{pH}$ (Table 5). These results find support from the relationship of $\mathrm{pH}$ with the divalent micronutrient cations $\left(\mathrm{Fe}^{2+}, \mathrm{Mn}^{2+}, \mathrm{Zn}^{2+}\right.$, $\mathrm{Cu}^{2+}$ ) that their activity or concentration in soil solution decreases 100-fold with each unit increase in $\mathrm{pH}$ (Lindsay, 1979). Several workers (Smith and Carson, 1981, Nadia and Zaghloul, 2006) showed that Co adsorption in soils increased with increasing $\mathrm{pH}$. The increase in soil solution $\mathrm{pH}$ results in increasing the negative surface charge of soil particle that allows the Co ion to have easier electrostatic reaction with the soil particles. Also at higher $\mathrm{pH}$, hydrolysis may cause precipitation of $\mathrm{Co}, \mathrm{Fe}$ and $\mathrm{Mn}$ ions.

Oxide Bound Cobalt (OX-Co), Manganese $(\mathrm{OX}-\mathrm{Mn})$ and Iron $(\mathrm{Ox}-\mathrm{Fe})$ : In surface and profile samples, the OX-Co content ranged from 0.72 to 1.39 $\mathrm{mg} \mathrm{kg}-1$ and 0.82 to $1.34 \mathrm{mg} \mathrm{kg}^{-1}$ and their respective mean content were 0.92 and $0.98 \mathrm{mg} \mathrm{kg}^{-1}$ soil (Table 3 and 4). The OX-Mn content in all the samples varied widely from 11.2 to $87.0 \mathrm{mg} \mathrm{kg}^{-1}$ and that of OX-Fe from 140 to $543 \mathrm{mg} \mathrm{kg}^{-1}$. The mean value of OXMn was 36.7 and $44.8 \mathrm{mg} \mathrm{kg}^{-1}$ and that of OX-Fe was 315.5 and $336 \mathrm{mg} \mathrm{kg}^{-1}$ in the surface and profile samples respectively (Tables 3 and 4). Histograms in Fig. 2 show that OX-Co and OX-Mn content noticeably increased with soil depth depicting nearly akin pattern of increase of both OX-Co and OX-Mn content with soil depth irrespective of the period of $\mathrm{R}-\mathrm{W}$ cultivation. Although OX-Co content slightly decreased and OX-Mn markedly increased with time 
Table 5: Relationship (coefficient of correlations) between and among soil properties and various fractions of Co, Mn and Fe in the soil profiles of Ludhiana block

\begin{tabular}{|c|c|c|c|c|c|c|c|c|}
\hline \multicolumn{9}{|c|}{ Correlation Matrix } \\
\hline & pH & EC & $\mathrm{OC}$ & $\mathrm{CaCO}_{3}$ & AA-Co & AA-Mn & AA-Fe & OX-Co \\
\hline pH & 1.000 & & & & & & & \\
\hline EC & -0.720 & 1.000 & & & & & & \\
\hline $\mathrm{OC}$ & -0.369 & $0.497 * *$ & 1.000 & & & & & \\
\hline $\mathrm{CaCO}_{3}$ & -0.119 & 0.100 & -0.462 & 1.000 & & & & \\
\hline AA-Co & -0.434 & 0.260 & -0.199 & 0.520 & 1.000 & & & \\
\hline AA-Mn & -0.043 & -0.241 & -0.323 & 0.581 & $0.538 * *$ & 1.000 & & \\
\hline $\mathrm{AA}-\mathrm{Fe}$ & -0.478 & 0.350 & -0.030 & 0.065 & $0.570 * *$ & -0.199 & 1.000 & \\
\hline Ox-Co & -0.292 & 0.072 & -0.191 & 0.660 & $0.697 * *$ & $0.746 * *$ & 0.183 & 1.000 \\
\hline Ox-Mn & 0.160 & -0.400 & -0.271 & 0.282 & -0.104 & $0.705^{* *}$ & $-0.673 * *$ & 0.382 \\
\hline \multirow[t]{2}{*}{ Ox-Fe } & 0.102 & -0.021 & -0.175 & -0.337 & 0.081 & $-0.469 *$ & $0.504 * *$ & $-0.437 *$ \\
\hline & Ox-Mn & $\mathrm{Ox}-\mathrm{Fe}$ & & & & & & \\
\hline Ox-Mn & 1.000 & & & & & & & \\
\hline Ox-Fe & -0.587 & 1.000 & & & & & & \\
\hline \multicolumn{9}{|c|}{ Critical value $(1-\mathrm{TAIL}, .05)=+/-0.427$} \\
\hline \multicolumn{9}{|c|}{ Critical value $(2$-tail, .05$)=+/-0.496$} \\
\hline $\mathrm{N}=16$ & & & & & & & & \\
\hline
\end{tabular}

lag of R-W cultivation but the overall trend of their increase with soil depth remained perceptible. This suggests their strong mutual association with the oxides component of soil. The close association of Co and Mn oxides in soils has been illustrated amazingly in electron micrographs of $\mathrm{Mn}$ accumulations in soils (McKenzie, 1975; Norrish, 1975). The outcome of the present study further indicates that leaching losses of both Co and Mn have taken place from the surface to sub-soil horizons during the submergence/reduced period of rice growth and subsequently their oxidation and accumulation has taken place in the sub-soil horizons especially under aerobic conditions during wheat season. It has been reported that under poor soil drainage condition, as seen in the investigated submerged soils under rice cultivation, reduction of soil minerals results in the concurrent release of Co (II) and Mn (II) as soluble
$\mathrm{Co}^{2+}$ and $\mathrm{Mn}^{2+}$ and their mobility is relatively high and may be transported by leaching to depth in the soil profile; where some Co may be retained in soil, mostly in oxides of $\mathrm{Mn}$, in association with layer silicates, organic colloids, or some lost in drainage waters (Mitchell, 1964; Uren, 2013). In these soils, Ox-Fe content markedly decreased with period of R$\mathrm{W}$ cultivation but increased with soil depth in the middle horizons, indicating, that its leaching from surface horizons and accumulation in the $15-45 \mathrm{~cm}$ horizon have also taken place. Also, mining of Co, $\mathrm{Mn}$ and Fe by R-W crops with prolonged period of their cultivation has contributed to decrease in their content in the soil-profile especially in the upper soil layers.

The conclusions of present study find support from the work of Wendling et al. (2007), who 
observed that after addition of soluble Co (II) to soil,it gets rapidly partitioned to the soil solid phase. And in alkaline soils a large percentage of this surfacebound Co was fixed through aging reactions in forms that were no longer in equilibrium with the soil solution Co. Analyses indicated that soil $\mathrm{pH}$ and incubation time were the most important factors affecting Co(II) aging. The rate and extent of aging/ fixation of added $\mathrm{Co}$ (II) was through reactions related to surface oxidation/precipitation or nucleation as driven by hydrolysis reactions at the surface of soil minerals. Similar fate of concurrently released $\mathrm{Co}^{+2}$, $\mathrm{Mn}^{+2}$ and $\mathrm{Fe}^{+2}$ under reduced soil conditions is expected in the present investigations. As leaching of $\mathrm{Co}^{+2}, \mathrm{Mn}^{+2}$ and $\mathrm{Fe}^{+2}$ in soil profile under submerged/reduced state under rice cultivation is followed by their accumulation, aging/fixation, particularly under oxidized/aerobic conditions of wheat cultivation for prolonged periods. This is anticipated especially in the coarse textured alkaline calcareous soils.

A positive and highly significant relation of $\mathrm{OX}$ Co with $\mathrm{CaCO}_{3}\left(\mathrm{r}=0.66^{* *}\right)$ and with AA-Co $(\mathrm{r}=$ $\left.0.70^{* *}\right)$ indicates that in these soils AA-Co is dependent on the content of Co-oxide $(\mathrm{CoO})$ which in turn is largely dependent on the soil $\mathrm{CaCO}_{3}$ content. Thus, the content of available Co (AA-Co), OX-Co and $\mathrm{CaCO}_{3}$ are inter-dependent in these soils. The positive and highly significant relation of $\mathrm{Ox}-\mathrm{Co}$ with AA-Mn $\left(\mathrm{r}=0.75^{* *}\right)$ and of AA-Mn with OX-Mn (r $\left.=0.71^{* *}\right)$ indicates that oxide bound Co are largely of Mn oxides compounds in these soils. This is consistent with the findings of several workers (Taylor and McKenzie, 1966; McKenzie, 1975; Norrish, 1975; McLaren et al., 1986b; Beak et al., 2011) that Co is closely associated with Mn oxides in soils and also Mn oxides strongly sorb/sequester Co. Furthermore, significant and negative relation of OX-Co with OX-Fe $\left(\mathrm{r}=-0.44^{*}\right)$ and positive with $\mathrm{OX}-\mathrm{Mn}(\mathrm{r}=0.38)$, as well as negative and significant relationship between OX-Mn and OX-Fe $(r=-$ $0.59 * *)$ suggests that oxide bound Co is largely depended on Mn oxides and not on Fe oxides. Several studies also revealed close association of Co with Mn oxides in soils (McKenzie 1967a, 1967b, 1970, 1975; Norrish 1975; Uren, 2013) because they have similar chemical properties. In a study on the effect of aging, intermittent submergence and in situ rice roots on the added Co distribution and speciation Beak et al. (2011) showed that during the aging and submerged-dried cycling, Co was found to be associated with Mn oxide fraction (23 to $100 \%$ of total $\mathrm{Co}$ ) and $\mathrm{Fe}$ oxide fractions (0 to $77 \%$ of total $\mathrm{Co}$ ) of the soils as either $\mathrm{Co}$ (II) species or a mixed $\mathrm{Co}$ (II) and $\mathrm{Co}$ in the +3 oxidation state (Co[III] species). Further, their in vivo root box experiments also showed similar Co speciation in the Mn oxide fraction (13 to $76 \%$ of total Co) with aging and submerged-dried cycling. But Fe oxide fraction of the soil was not that important in Co retention. Significant and positive relation of AA-Fe with OX$\mathrm{Fe}\left(\mathrm{r}=0.50^{* *}\right)$ and negative with OX-Mn $(\mathrm{r}=$ $0.67 * *)$ indicates that AA-Fe is largely dependent on the content of Fe-oxides and not on Mn-oxides (Table $5)$.

\section{Ferozepur Block}

The data in Tables 3 and 4 shows that soil $\mathrm{pH}$ ranged from 7.02 to 8.76 in the surface and 7.20 to 9.0 in the profiles soil samples with a respective mean value of 8.12 and 8.26. These sets of data indicate that the soils are alkaline in nature. The salt content (EC) varied from 0.129 to 1.07 and 0.129 to $1.07-\mathrm{dSm}^{-1}$ in the surface and profile samples with mean content of 0.45 and $0.41-\mathrm{dSm}^{-1}$ respectively. The salt concentration was nearly 1.7 and 2.6-fold higher than that of the respective content in the soils of Ludhiana block, thus pointing out that these soils are more saline than that of Ludhiana block. The $\mathrm{CaCO}_{3}$ content ranged widely from 1.0 to $9.2 \%$ and 1.0 to $8.0 \%$ with a mean content of 3.0 and $3.2 \%$ in the surface and profile samples respectively. These soils were 1.4 and 1.14-fold more calcareous than that of Ludhiana block. The OC content in all the soils ranged from 0.12 to $0.87 \%$ and 0.085 to $0.75 \%$ with a mean content of 0.456 and $0.260 \%$ in the surface and profile samples respectively suggesting that these soils contain low organic matter content.

The histograms in Fig. 3 reveal that soil $\mathrm{pH}$ moderately increased and decreased in the alternate soil horizon but has an overall tendency to increase with soil depth across the period of R-W cultivation. 


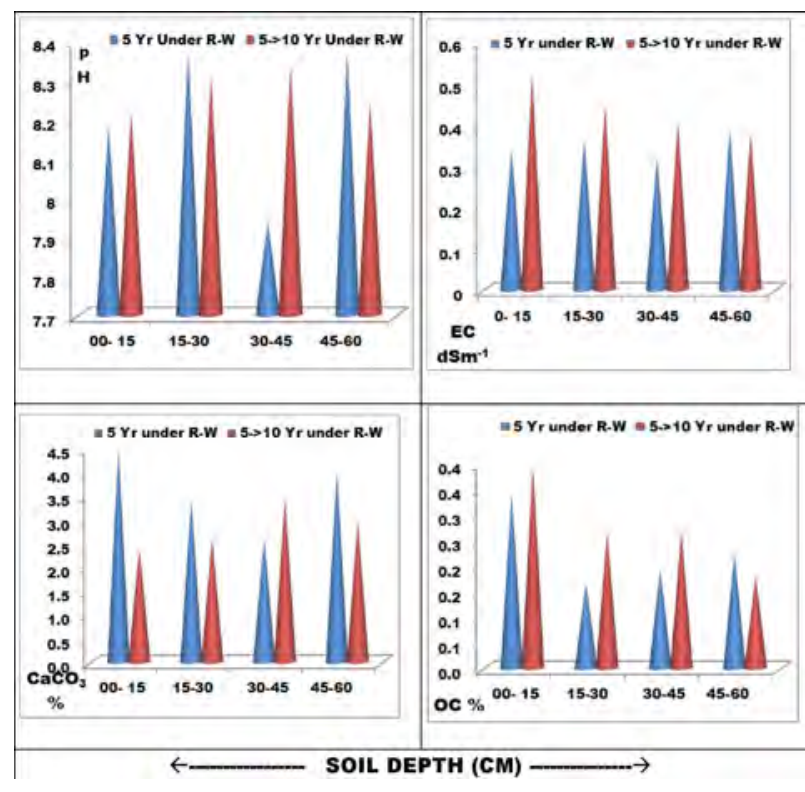

Fig. 3: Changes in soil pH, EC, OC and $\mathrm{CaCO} 3$ content with periods of $R$-W cultivation in 15- soil profiles of Ferozepur block

The $\mathrm{CaCO}_{3}$ content markedly decreased with soil depth in the profiles under R-W cultivation for 5 years. However, with period of R-W cultivation for 10 or more years its content though decreased but increased appreciably with soil depth. This appears to have resulted due to its dissolution and leaching of $\mathrm{Ca}$ during submerged/reduced condition of rice cultivation. Both EC and OC content decreased appreciably with soil depth but increased clearly with time lag of R-W cultivation (Fig. 3). This appears to have resulted from the input of salt through irrigation with ground water as aquifer of this region is saline to highly saline. Also the average EC value was 1.72.6 fold higher than that of its content in the soils of Ludhiana block (Table 3 and 4). The slight increase in OC content with period of R-W cultivation appears to have resulted from the incremental addition of root biomass with cultivation of RWCS.

Available Cobalt (AA-Co): The available Co content in the soils of Ferozepur block ranged from 0.04 to $0.87 \mathrm{mg} \mathrm{kg}^{-1}$ and 0.01 to $0.76 \mathrm{mg} \mathrm{kg}^{-1}$ with a mean content of 0.28 and $0.30 \mathrm{mg} \mathrm{kg}^{-1}$ in the surface and profiles samples respectively (Table 3 and 4). AA-Co appreciably decreased with periods of 10-15 years of R-W cultivation but increased with soil depth from $15-30 \mathrm{~cm}$ onwards (Fig. 4). It should be due to

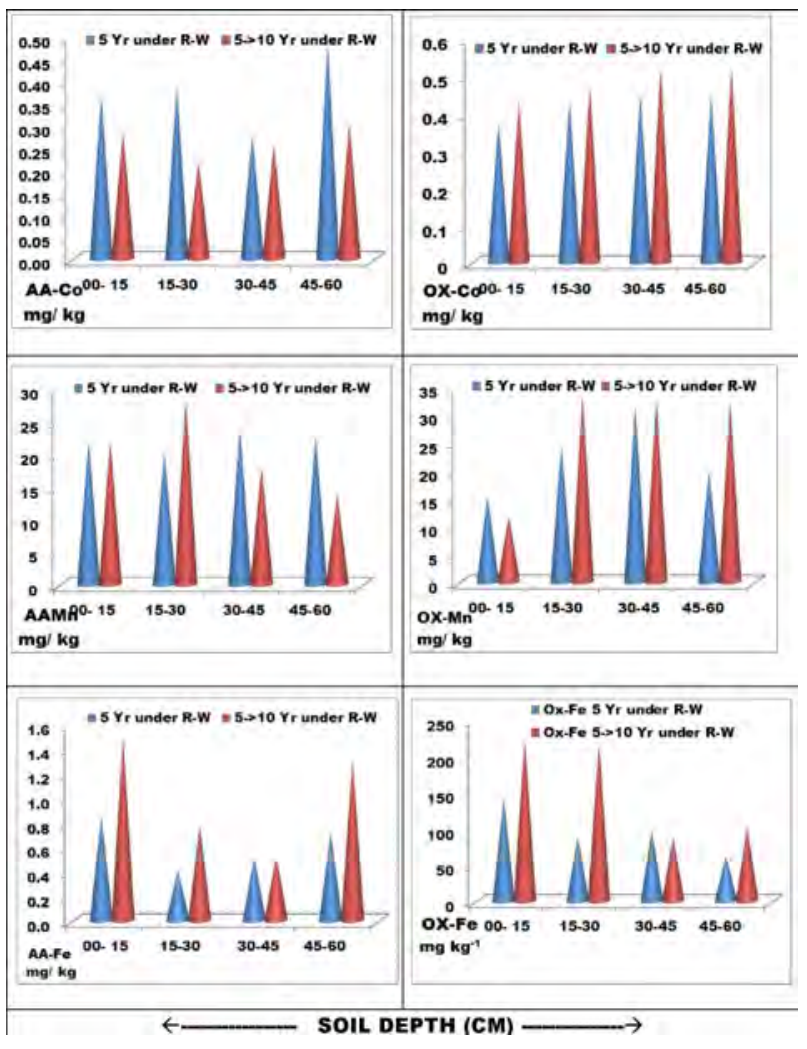

Fig. 4: Changes in acetic acid (AA) extractable and oxide (OX) fractions of $\mathrm{Co}$, Mn and Fe content in 15 soil profiles under different periods of $\mathrm{R}$-W cultivation in Ferozepur block

leaching of Co down the profile under submerged rice culture conditions. The weathering of Co-bearing $\mathrm{Fe}$ and $\mathrm{Mn}$ minerals is faster under submerged, waterlogged and impeded drainage conditions and thus, conducive for the released Co to leaching in coarse textured permeable soils under submerged rice culture conditions. This is consistent with the results of Swaine and Mitchell (1960) that under reduced/ anaerobic conditions of restricted drainage, the most marked effect on the contents of extractable Co was increase in its mobilization and very high extractable Co contents in the gleyed horizons. Soil mobility of Co has been reported to be inversely related to the strength of adsorption by soil constituents (Kim et al., 2006), it is expected to be lesser in the investigated coarse-textured sandy soils than in fine-textured clayey soils. As a rule, Co and Mn are lowest in coarse grained sediments (sandstones, sand) and highest in fine-grained sediments (shale's, clay). Besides, R-W crops depleted large amount of Co from the $0-30 \mathrm{~cm}$ horizons over the years. However, slightly higher 
content of AA-Co in $0-15 \mathrm{~cm}$ than $15-45 \mathrm{~cm}$ horizons appears to have resulted from the higher organic matter content that forms complexes with Co. McLaren et al. (1986 b) reported that substantial amount of Co was absorbed by humic and fulvic acids but it remained as easily isotopically exchangeable. Humus is capable of adsorbing Co due to the ion exchange capability and its chelating effect, but Co can be replaced easily by other cations and perhaps humus lacks the capability of binding Co permanently (Arent, 1959).

$A A-M n$ and $A A-F e$ : The AA-Mn fraction in the surface and profile samples varied from 1.46 to 41.0 and 8.5 to $41.0 \mathrm{mg} \mathrm{kg}^{-1}$ with a mean value of 23.1 and $21.2 \mathrm{mg} \mathrm{kg}^{-1}$ respectively. The AA-Fe ranged from 0.28 to 12.22 and 0.12 to $3.74 \mathrm{mg} \mathrm{kg}^{-1}$ with a mean value of 1.61 and $0.86 \mathrm{mg} \mathrm{kg}^{-1}$ respectively (Table 3 and 4). In all the profiles, both AA-Fe and
AA-Mn, markedly increased up to $30 \mathrm{~cm}$ horizon with time lag of R-W cultivation. These fractions though decreased with soil depth but increased visibly in the $15-30 \mathrm{~cm}$ horizon suggesting their leaching from the surface and accumulation largely in $15-30 \mathrm{~cm}$ horizons (Fig. 4). Though there is an analogous pattern of distribution of AA-Mn and AA-Fe but the relationship between the two, as well as, with that of AA-Co was non-significant.

The $\mathrm{CaCO}_{3}$ content is quite high in these soils. It dominated and largely regulated the available Co (AA-Co) content as demonstrated by the significant correlation $\left(\mathrm{r}=0.433^{* *}\right)$ between the two (Table 6). As the $\mathrm{pH}$ is a very prominent factor that regulates the mobility of $\mathrm{Co}$ and also determines the concentration of the naturally occurring hydroxyl $(\mathrm{OH})^{-}$, bicarbonate $\mathrm{HCO}_{3}{ }^{-}$and carbonate $\left(\mathrm{CO}_{3}\right)^{2-}$ ions, the concentration of these anions increases with

Table 6: Relationship (coefficient of correlations) between and among soil properties and various fractions of Co, Mn and Fe in the soil profiles of Ferozepur block

\begin{tabular}{|c|c|c|c|c|c|c|c|c|}
\hline \multicolumn{9}{|c|}{ Correlation Matrix } \\
\hline & pH & EC & OC & $\mathrm{CaCO}_{3}$ & AA-Co & AA-Mn & AA-Fe & OX-Co \\
\hline pH & 1.000 & & & & & & & \\
\hline EC & -0.038 & 1.000 & & & & & & \\
\hline OC & $-0.258 *$ & 0.216 & 1.000 & & & & & \\
\hline $\mathrm{CaCO}_{3}$ & -0.069 & 0.069 & -0.160 & 1.000 & & & & \\
\hline AA-Co & 0.227 & 0.083 & -0.077 & $0.433 * *$ & 1.000 & & & \\
\hline AA-Mn & -0.100 & 0.163 & 0.107 & 0.048 & -0.122 & 1.000 & & \\
\hline AA-Fe & $-0.482 * *$ & $0.280 *$ & $0.591 * *$ & -0.107 & 0.035 & -0.026 & 1.000 & \\
\hline Ox-Co & -0.132 & -0.052 & $-0.419 * *$ & $-0.253^{*}$ & $-0.315 * *$ & -0.143 & $-0.250 *$ & 1.000 \\
\hline Ox-Mn & -0.226 & -0.054 & $-0.433 * *$ & -0.094 & $-0.534 * *$ & 0.027 & $-\mathbf{0 . 3 3 8} * *$ & $0.628 * *$ \\
\hline \multirow[t]{2}{*}{ Ox-Fe } & $-0.352 * *$ & $0.302 * *$ & $0.354 * *$ & -0.158 & $-0.253 *$ & 0.164 & $0.385 * *$ & 0.001 \\
\hline & & Ox-Mn & $\mathrm{Ox}-\mathrm{Fe}$ & & & & & \\
\hline Ox-Mn & 1.000 & & & & & & & \\
\hline Ox-Fe & 0.057 & 1.000 & & & & & & \\
\hline \multicolumn{9}{|c|}{ Critical value $(1-$ TAIL, .05$)=+$ Or -0.240} \\
\hline \multicolumn{9}{|c|}{$\begin{array}{l}\text { Critical value (2-tail, .05) }=+/-0.284 \\
\mathrm{~N}=48\end{array}$} \\
\hline
\end{tabular}


increase in $\mathrm{pH}$ and around or beyond neutrality. As is the case in the investigated soils where $\mathrm{pH}$ ranges from 7.0 to 9.0 and $\mathrm{CaCO}_{3}$ from 1.0 to $9.2 \%$, the cobaltous $\mathrm{Co}^{2+}[\mathrm{Co}(\mathrm{II})]$ or cobaltic $\mathrm{Co}^{3+}[\mathrm{Co}$ (III) $]$ ions or species start precipitating as insoluble $\mathrm{Co}(\mathrm{OH})_{2}$, $\mathrm{Co}(\mathrm{OH})_{3}$ and $\mathrm{CoCO}_{3}$. Thus, Co forms insoluble compounds with two important naturally occurring anions, the $\mathrm{OH}^{-}$ion and the $\left(\mathrm{CO}_{3}\right)^{2-}$ ion, and both $\mathrm{Co}$ (II) and Co (IIl) will precipitate as insoluble hydroxide or carbonate, once the solubility product is surpassed. Similarly, formation of $\mathrm{Mn}$ and Fecarbonates occurs in soils containing high $\mathrm{pH}$ and $\mathrm{CaCO}_{3}$ content. Several researchers have shown that as $\mathrm{pH}$ increases, insoluble hydroxides and carbonates may form that also reduce Co concentration in soil solution, its mobility and availability (Tiller and Hodgson, 1962; Sanders, 1983; Li et al., 1999, 2004; Kim et al., 2006). Further, Anderson and Christensen (1988) observed a significant linear correlation between soil $\mathrm{pH}$ and the sorption (sorption coefficient, $\mathrm{Kd}$ ) of $\mathrm{Co}$ in 38 soils ( $\log \mathrm{Kd}=0.7-2.29$ $\left.\mathrm{pH}, \mathrm{R}^{2}=0.81\right)$. This is somewhat similar to the relationship reported by Bakkaus et al. (2008) (log $\mathrm{Kd}=1.1-5.2 \mathrm{pH}, \mathrm{R}^{2}=0.71$. Therefore, soil solution concentrations of Co would be expected to vary by, approximately, an order of magnitude with each unit change of soil pH (Collins and Kinselaa, 2010).

The present conclusions gain further support from the significant negative relationships reported between DTPA extractable Co and $\mathrm{pH}$ as well with $\mathrm{CaCO}_{3}$ in alkaline calcareous soils of Yavatmal district of Maharashtra, India (Kabir et al., 2014) and between available $\mathrm{Co}$ (AA-Co) and $\mathrm{pH}$ in the alluvial soils of Jalhandur district of Punjab (Bansal et al., 1991; Singh et al., 1980). Morrison et al. (1997) also observed that soil $\mathrm{pH}$ is one of the most important factors governing Co sorption and its bio-availability in soil system. The study of Han et al. (2002) lends support to these findings. They observed that during the long-term saturated incubation, Co in six arid soils was redistributed among the solid phases mainly from the Mn oxide bound, and to some extent, Fe oxide bound and organic matter bound fractions into the carbonate bound fraction. Further, Wendling et al. (2009) observed that added soluble Co (II) to alkaline soils get rapidly partitioned to the soil solid phase. A large percentage of the solid phase Co was fixed through aging reactions. They found that soil $\mathrm{pH}$ and incubation time were the most important factors affecting Co aging. The rate and extent of aging/ fixation of Co was through reactions related to surface oxidation/precipitation/nucleation as driven by hydrolysis reactions at the surface of soil minerals.

The similar pattern of distribution of AA-Fe, $\mathrm{EC}$ and $\mathrm{OC}$ in these profiles as well as significant positive relationship of AA-Fe with OC $\left(\mathrm{r}=0.591^{* *}\right)$ and EC $\left(r=0.280^{*}\right)$ indicate that $\mathrm{OC}$ and salt content largely and positively control the AA-Fe in these soils. The reverse trend of distribution of $\mathrm{AA}-\mathrm{Fe}$ and $\mathrm{pH}$ and negative and significant relationship between the two $(\mathrm{r}=-0.402)$ establish that $\mathrm{pH}$ largely and negatively regulate the content of AA-Fe in these soils. However, the relationships of soil properties with AA-Co and AA-Mn were non-significant (Table $6)$.

Oxide bound Cobalt (OX-Co), Manganese (OX$\mathrm{Mn})$ and Iron $(\mathrm{OX}-\mathrm{Fe})$ : In the Ferozepur soils, these fractions varied widely. The OX-Co content in all the soils ranged from 0.02 to 1.10 and $0.14-1.124 \mathrm{mg}$ $\mathrm{kg}^{-1}$ with mean value of 0.32 and $0.47 \mathrm{mg} \mathrm{kg}^{-1}$ in the surface and profile soils respectively. The OX-Mn content varied from 0.4 to 90.9 and 4.3 to $83.9 \mathrm{mg}$ $\mathrm{kg}^{-1}$ with mean content of 14.9 and $26.1 \mathrm{mg} \mathrm{kg}^{-1}$ respectively in the surface and profile soils. The content of OX-Fe ranged from 24 to 401 and 7 to $401 \mathrm{mg} \mathrm{kg}^{-1}$ with a mean level of 176 and $141 \mathrm{mg}$ $\mathrm{kg}^{-1}$; that is 11.8 and 5.4-fold greater than OX-Mn, in the surface and profile soils respectively. The histograms in Fig. 4 show analogous pattern of increase of both OX-Co and OX-Mn content with increase in soil depth and period of R-W cultivation. This suggests that leaching losses of both Co and Mn have concurrently taken place from the surface to subsoils horizons; the cause for the same has been discussed earlier under Ludhiana block soils. Also, $\mathrm{R}-\mathrm{W}$ crops have mined considerable amount of these elements from the surface horizons for 10-15 years and may have contributed to some extent to the observed trend of their distribution in the profiles. AA-Co is negatively and significantly related with both OX-Mn and OX-Fe suggesting that the decrease 
in AA-Co has taken place due to increase in its sorption with the increasing content of Mn oxides that are known to sequester Co (Norrish, 1975; McLaren et al., 1986b and Beak et al., 2011). Further, studies have shown that Fe-oxides also bind or adsorb Co in addition to a number of other trace elements (Jenne, 1968; Grimme, 1968 and Le Riche, 1973). In the present study, strong significant positive correlation between the Ox-Co and OX-Mn ( $\mathrm{r}=0.63)$ demonstrate their mutual association in these soils (Table 6). These findings find support from the results of McKenzie (1967a, 1967b, 1970), who showed that on an average, Mn-minerals adsorbed 20-times more $\mathrm{Co}$ and only 6-times more $\mathrm{Cu}$ as compared to the associated soil materials. The non-extractable fraction of the Co further increased on aging of the mineral after sorption, and released more Mn into solution suggesting that $\mathrm{Co}$ is able to replace $\mathrm{Mn}^{3+}$ in the crystal lattice, thereby explaining the high concentration of Co found in manganiferous materials in soils. Similarly, strong relationship between Co with $\mathrm{Mn}$ have been reported by several researchers (Li, 2000; Baize and Sterckeman, 2001; Schuiling et al., 2003 and Cappuyns and Mallaerts, 2014). Also, work of McLaren et al. (1986a, 1986b) showed that soil-derived oxide materials absorbed by far the greatest amounts of $\mathrm{Co}$ in non-isotopically exchangeable form. Likewise, Oertel and Giles (1964) noted a correlation between Co and Mn and alluded that $\mathrm{Co}$ is associated with Mn-oxides. The simple oxides and hydroxides of Mn occur in soils in mineralogical forms as lithiophorite [( $\mathrm{Al}, \mathrm{Li}) \mathrm{MnO}_{2}$ $\left.(\mathrm{OH})_{2}\right]$, birnessite [( $\left.\left.\mathrm{Na}_{0.7} \mathrm{Ca}_{0.3}\right) \mathrm{Mn}_{7} \mathrm{O}_{14} \cdot 2.8 \mathrm{H}_{2} \mathrm{O}\right]$, hollandite $\left[\mathrm{Ba}_{2} \mathrm{Mn}_{8} \mathrm{O}_{16}\right]$ (Norrish, 1975) and $[\delta$ $\left.\mathrm{MnO}_{2}\right]$. The crystalline size of these minerals is very small $(0.02-0.1 \mu \mathrm{m})$ and subsequently, the surface area is very large (up to $350 \mathrm{~m}^{2} \mathrm{~g}^{-1}$ of Birnessite), which imparts extraordinary sorptive properties and colloidal characteristics. The zero surface charge of these minerals is in the lower $\mathrm{pH}$ range; consequently the Mn-oxides have a high negative surface charge thereby, the high cation or Co adsorption capacity over a very wide range of $\mathrm{pH}$. Further, Crerar et al. (1980) and Taylor and McKenzie (1966) showed that in Australian soils most of the Co $(79 \%)$ is associated with the Mn-oxides, in particular, or associated with hollandite, crptomelane, psilomelane, lithiophorite, birnessite minerals. Furthermore, in the investigated soils, significant negative relationship of OC content with OX-Co $\left(\mathrm{r}=-0.42^{* *}\right)$ and $\mathrm{OX}-\mathrm{Mn}\left(\mathrm{r}=-0.43^{* *}\right)$ indicates that decrease in organic matter content caused an increase in both OX-Co and OX-Mn content. This may have resulted due to decreasing level of organic or humic acid fraction that restrains OX-Mn to bind or form complex with Co.

The substantial increase in OX-Fe in the surface horizons $(0-30 \mathrm{~cm})$ than in the sub-surface horizons after 5-10 years period of R-W cultivation (Fig. 4) appears to have resulted from the reduction and or solubilization of higher oxides of Fe during reduced conditions of rice cultivation and subsequent its oxidation and accumulation in the surface horizons under oxidized conditions of wheat cultivation because of higher oxidation potential of $\mathrm{Fe}$ than that of $\mathrm{Mn}$. Also, soil properties like $\mathrm{pH}, \mathrm{EC}$ and OC influenced the pattern of distribution of $\mathrm{OX}-\mathrm{Fe}$ content in these soils. An increase in EC and OC content caused an increase in OX-Fe. The significant positive relations of $\mathrm{OX}-\mathrm{Fe}$ with $\mathrm{EC} \mathrm{r}=0.30^{* *}$ and $\mathrm{OC} \mathrm{r}=0.35^{* *}$ indicate that $\mathrm{OX}-\mathrm{Fe}$ is modestly moderated by OC and salt content in these soils (Table $6)$.

\section{Faridkot and Kotkapura Blocks}

The $\mathrm{pH}$ and salt content (EC) in these soils ranged widely from 7.35 to 9.68 and 0.24 to $3.9 \mathrm{dSm}^{-1}$ respectively. Their respective mean values were 8.69 and $0.87 \mathrm{dSm}^{-1}$ in the surface and 8.28 and 0.51 $\mathrm{dSm}^{-1}$ in the profile samples. This suggests that these soils are more saline and alkaline than that of Ludhiana and Ferozepur blocks. The range of $\mathrm{CaCO}_{3}$ and $\mathrm{OC}$ content was also huge and varied from 1.0 to $9.5 \%$ of $\mathrm{CaCO}_{3}$ and 0.10 to $0.60 \%$ of $\mathrm{OC}$ with their mean values of 4.3 and $0.34 \%$ in the surface soils and 4.59 and $0.27 \%$ in the profile samples respectively. Thus, these soils are more calcareous and contain lesser organic matter than the soils of Ludhiana and Ferozepur Blocks (Table 3 and 4).

The histograms in Fig. 5 illustrate that $\mathrm{pH}$ markedly increased both with time of R-W cultivation and soil depth. While reverse was the trend of salt 


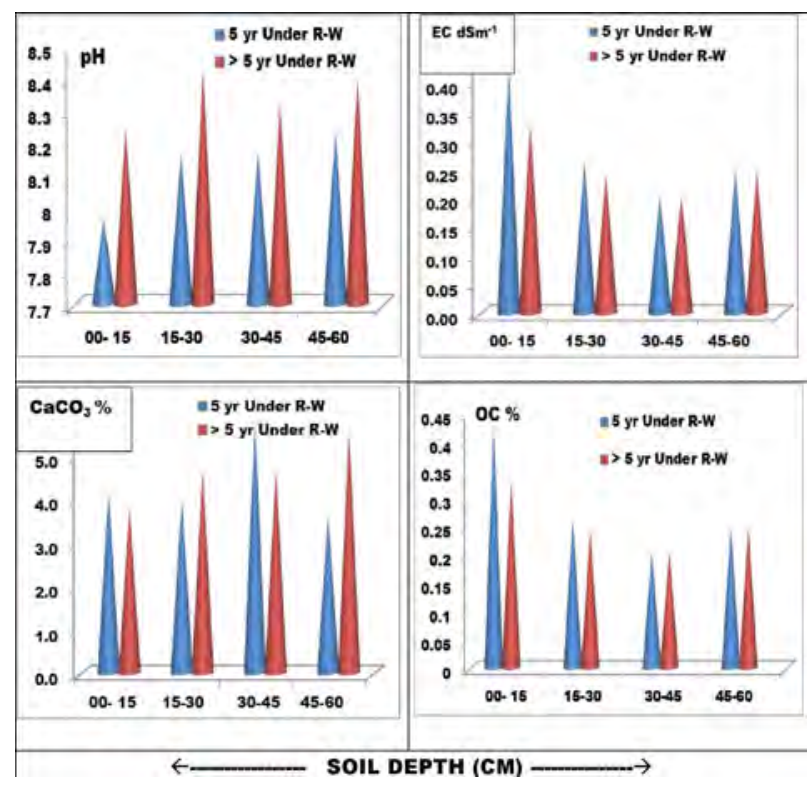

Fig. 5: Changes in soil $\mathrm{pH}, \mathrm{EC}, \mathrm{OC}$ and $\mathrm{CaCO}_{3}$ content with periods of $R-W$ cultivation in 15-soil profiles of Faridkot-Kotkapura blocks

content (EC) that decreased both with time of R-W cultivation and with soil depth. The significant negative relationship between $\mathrm{EC}$ and $\mathrm{pH}$ in the profiles under R-W cultivation for 5 years $(\mathrm{r}=$ $\left.0.51^{* *}\right)$ and in the surface soil samples $\left(\mathrm{r}=-0.48^{* *}\right)$ substantiate this. This signifies that as salt content decreases the $\mathrm{pH}$ increases in these soils. The $\mathrm{CaCO}_{3}$ content moderately increased with soil depth but depicted inconsistent trend with time of R-W cultivation. The data in Table 7 show that salt content regulated positively and significantly the $\mathrm{CaCO}_{3}$ content in all the profile samples $\left(\mathrm{r}=0.25^{*}\right)$. The soil OC content moderately decreased with soil depth but increased with time of R-W cultivation (Fig. 5) due to continuous addition of organic matter as root biomass of crops for 5-10 year period of cultivation. Inverse distribution pattern of $\mathrm{CaCO}_{3}$ and $\mathrm{OC}$ content was observed in the profiles and a significant negative relation $(\mathrm{r}=-0.27 * *)$ between the two substantiate this (Table 7).

The AA-Mn fraction in these soils varied hugely from 0.3 to $24.0 \mathrm{mg} \mathrm{kg}^{-1}$ with a mean content of 8.76 and $7.80 \mathrm{mg} \mathrm{kg}^{-1}$ respectively in the surface and profile samples. Also AA-Fe widely ranged from 0.01 to $3.40 \mathrm{mg} \mathrm{kg}^{-1}$ with a mean value of 0.72 and 0.63

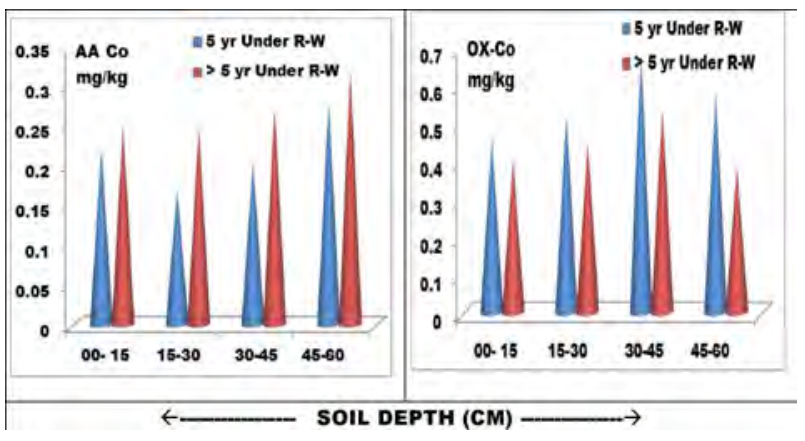

Fig. 6: Changes in AA-Co and OX-Co content with periods of R-W cultivation in 15-soil profiles of Faridkot-Kotkapura blocks

mg kg-1 respectively in the surface and profile soils. The histograms in Fig. 7 clearly illustrate that AA$\mathrm{Mn}$, beyond the $0-15 \mathrm{~cm}$ surface horizon, markedly increased both with depth and time lag of R-W cultivation. This suggests reduction and mobilization of $\mathrm{Mn}$ and consequently its leaching has taken place in these coarse textured soils under prolonged period of reduced rice culture conditions. The reasons for the same have been elaborated under Ludhiana and Ferozepur blocks. The higher content of AA-Mn in the surface horizon may be due to high OC content $(0.4-0.45 \%)$ as well as $\mathrm{MnO}_{2}$ in this horizon.

The AA-Fe content appreciably decreased up to $45 \mathrm{~cm}$ soil depth. Beyond that it increased moderately. But with time of R-W cultivation it showed inconsistent pattern of distribution (Fig. 7). In the surface soils, AA-Mn was significantly and negatively related with soil $\mathrm{pH}(\mathrm{r}=-538 * *)$ suggesting that $\mathrm{pH}$ significantly regulate the AA-Mn content in these soils. This appears to have resulted due to oxidation of $\mathrm{Mn}$ or its conversion to insoluble forms with increase in $\mathrm{pH}$. It has been shown that

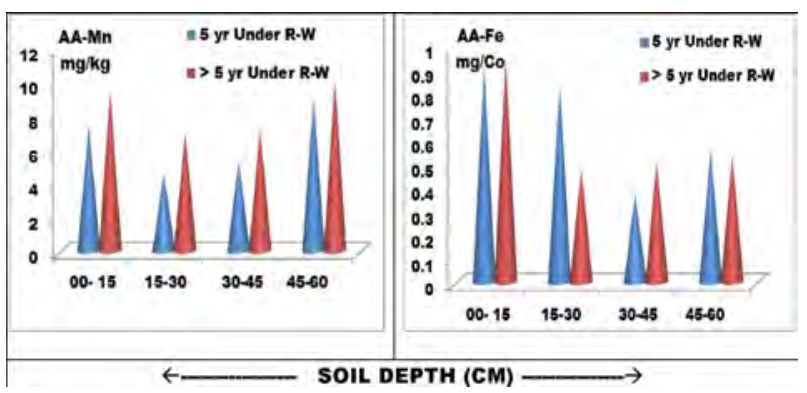

Fig. 7: Changes in AA-Mn and AA-Fe content with periods of R-W cultivation in 15-soil profiles of Faridkot-Kotkapura blocks 
with each unit increase in $\mathrm{pH}$ the $\mathrm{Mn}^{2+}$ in soil solution decreases by 100-fold (Lindsay, 1979). Soil OC moderated the content of AA-Fe, the similar pattern of their distribution as well as significant and positive relationship between the two $\left(\mathrm{r}=0.351^{* *}\right)$ validate the same (Table 7; Fig. 5 and 7). The significant and positive relation between AA-Co and AA-Fe ( $\mathrm{r}=$ $0.430^{* *}$ ) suggests that these fractions are probably controlled by the same soil source and properties.

Available Cobalt (AA-Co): The available Co content in these soils ranged widely between 0.2 and $0.54 \mathrm{mg} \mathrm{kg}^{-1}$ with mean value of $0.25 \mathrm{mg} \mathrm{kg}^{-1}$ in the surface and profile soils. The histograms in Fig. 6 depict that the available Co content appreciably increased both with soil depth and time lag of R-W cultivation. This seemingly has resulted largely due to its leaching down the profiles of these coarse textured soils under protracted period of reduced soil condition of rice cultivation. In addition, $\mathrm{R}-\mathrm{W}$ crops depleted considerable amount of $\mathrm{Co}$ from the surface 0-30 cm soil horizons. The higher content of AA-Co in the surface $0-15 \mathrm{~cm}$ layer than in the $15-45 \mathrm{~cm}$ layers was due to higher OC content in the former layer that form complexes with Co or sorb it. McLaren et al. (1986a, 1986b) reported that substantial amounts of Co were adsorbed by organic materials humic and fulvic acids but it remained as easily isotopically exchangeable. Humus is capable of adsorbing Co due to the ion exchange capability and its chelating effect, but Co can be replaced easily by other cations. The pattern of distribution of AA-Co and $\mathrm{pH}$ is akin and that of AA-Co and EC is dissimilar. Significant negative relationships between EC and AA-Co $\left(\mathrm{r}=-0.29^{* *}\right)$ and positive between $\mathrm{pH}$ and AA-Co $\left(r=0.22^{*}\right)$ suggest that EC and $\mathrm{pH}$ modestly moderate the available Co content in these soils (Table 7).

Oxide Bound Cobalt (Ox-Co): In these soils only OX-Co was estimated. It varied from 0.14 to $1.52 \mathrm{mg} \mathrm{kg}^{-1}$ with a mean value of 0.40 and $0.48 \mathrm{mg}$ $\mathrm{kg}^{-1}$ in surface and profile samples respectively. Soil $\mathrm{pH}$ influenced negatively the OX-Co content in these soils. The significant negative relationship between the two $(\mathrm{r}=-0.27 * *)$ substantiate this. This is in agreement with the findings of Sandres (1983) that increase in $\mathrm{pH}$ of soil solution of a sandy loam soil caused decrease in Co concentration as well as, increase in its adsorption (Smith and Carson, 1981; Nadia and Zaghlou, 2006). The histograms in Fig. 6 depict that both Ox-Co and AA-Co content increased

Table 7: Relationship (coefficient of correlations) between and among soil properties and various fractions of $\mathrm{Co}, \mathrm{Mn}$ and Fe in the soil profiles of Faridkot-Kotkapra blocks

\begin{tabular}{|c|c|c|c|c|c|c|c|c|}
\hline \multicolumn{9}{|c|}{ Correlation Matrix } \\
\hline & $\mathbf{p H}$ & EC & OC & $\mathrm{CaCO}_{3}$ & AA-Co & AA-Mn & AA-Fe & OX-Co \\
\hline pH & 1.000 & & & & & & & \\
\hline EC & -0.125 & 1.000 & & & & & & \\
\hline OC & 0.095 & 0.003 & 1.000 & & & & & \\
\hline $\mathrm{CaCO}_{3}$ & -0.065 & $-0.248 *$ & $-0.271 * *$ & 1.000 & & & & \\
\hline AA-Co & $0.216 *$ & $-0.294 * *$ & 0.104 & -0.089 & 1.000 & & & \\
\hline AA-Mn & 0.066 & 0.113 & -0.073 & 0.004 & -0.123 & 1.000 & & \\
\hline $\mathbf{A A}-\mathbf{F e}$ & 0.141 & -0.210 & $0.351 * *$ & -0.195 & $\mathbf{0 . 4 3 0} * *$ & -0.117 & 1.000 & \\
\hline Ox-Co & $-0.273 * *$ & -0.064 & -0.207 & 0.110 & $-0.316^{* * *}$ & -0.214 & $-0.277 * *$ & 1.000 \\
\hline \multicolumn{9}{|c|}{ Critical value $(1-\mathrm{TAIL}, .05)=+$ Or -0.215} \\
\hline \multicolumn{9}{|c|}{ Critical value $(2$-tail, .05$)=+/-0.254$} \\
\hline$N=60$ & & & & & & & & \\
\hline
\end{tabular}


with soil depth irrespective of the period of R-W cultivation, indicating, that leaching of both the fractions has taken place in these coarse textured soils under reduced conditions of rice cultivation. The processes and factors involved in the leaching of Co are discussed earlier under Ludhiana and Ferozepur blocks. However, the content of Ox-Co decreased and AA-Co content increased with time of R-W cultivation suggesting that AA-Co has largely originated from the OX-Co fraction and as a result OX-Co content decreased in each of the soil horizon. Hence, both fractions maintained the same trend of decrease with soil depth. Significant negative relationship between AA-Fe and $\mathrm{OX}-\mathrm{Co}(\mathrm{r}=-0.28 * *)$ suggests that AA-Fe is not dependent on OX-Co fraction, but largely on soil OC content as elucidated earlier.

\section{Cobalt Deficiency Status in the Soils of Ludhiana, Ferozepur, Faridkot-Kotkapura Blocks}

Available Co content in the surface soil samples of Ludhiana, Ferozepur and Faridkot-Kotkapura blocks ranged from 0.10 to $0.54,0.04$ to 0.87 and 0.02 to $0.54-\mathrm{mg} \mathrm{kg}^{-1}$ respectively. Considering $0.25-\mathrm{mg} \mathrm{Co}$ $\mathrm{kg}^{-1}$ as the deficient level (Mitchell, 1945 and Stewart, 1953) and 0.37-mg Co kg-1 as marginally deficient level, nearly 25 and 45, 42 and 32, 47 and $36 \%$ soils indicated Co deficiency and marginal deficiency respectively in Ludhiana, Ferozepur and Faridkot-Kotkapura blocks. The overall status of Co deficiency and marginal deficiency in all the four blocks was 42 and $35 \%$, respectively (Fig. 8). The

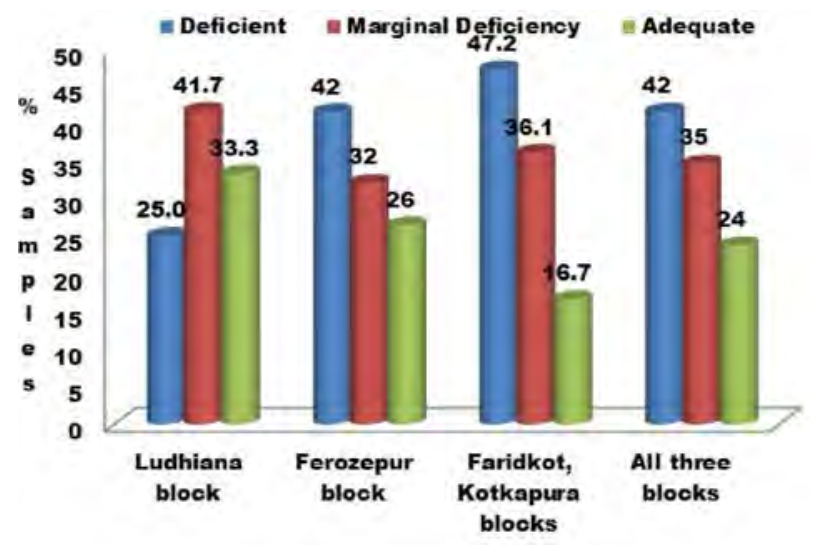

Fig. 8: Cobalt deficiency in coarse textured calcareous soils under rice-wheat cropping system for 5-20 years in Punjab deficiency of Co in these soils appear to have resulted partly because of its depletion by the R-W crops from the surface soil layer and largely due to its leaching down in these coarse textured calcareous soils under protracted period of reduced soil condition of rice cultivation. As a consequence of these processes, available Co content in these soils dropped below the critical level of deficiency.

\section{Conclusions}

The long term cultivation of irrigated rice-wheat cropping system in coarse textured calcareous alluvial soils causes leaching losses of Co along with Mn from the surface soil horizons to the sub-surface horizons. In these soils, Co co-exist largely with manganese oxides that get reduced, solubilized and simultaneously release the associated or adsorbed Co during the anaerobic submerged soil condition under rice cultivation that cause their concurrent movement and leaching. Also $\mathrm{Co}, \mathrm{Mn}$ and $\mathrm{Fe}$ co-exist as carbonates in these calcareous soils and meet the same fate. These processes cause depletion of Co from the surface soils leading to its decline below the critical level of deficiency as nearly $42 \%$ soils are found deficient in Co. Further, research needs to be undertaken to establish the occurrence of Co deficiency through response of nodulated crops in these soils. Also, its contribution in $\mathrm{N}_{2}$ fixation and supplementation in the soil-cropping system involving nodulated crops needs to be studied because rice cultivation is considered to be the cause of ground water depletion and emission of greenhouse gases. It is suggested that this needs to be replaced especially with nodulated pulses and oilseed crops.

\section{Acknowledgement}

Author is thankful to INSA and ICAR, New Delhi for the grant of funds for this study and the Head, Division of Soil Science and Agricultural Chemistry, IARI, New Delhi for the laboratory facilities for the research work and the Head Department Soils, PAU, Ludhiana for providing facility for estimation of Co, $\mathrm{Mn}$ and $\mathrm{Fe}$ on AAS. 


\section{References}

Adams S N and Honeysett J L (1964) Some effects of waterlogging on the cobalt and copper status of pasture plants in pots Aust J Soil Res 15 357-367

Anderson P R and Christensen T H (1988) Distribution coefficients of $\mathrm{Cd}, \mathrm{Co}, \mathrm{Ni}$, and $\mathrm{Zn}$ in soils J Soil Sci 39 $15-22$

Arent H (1959) Die Spurenelementeim Dungervesen. (Literature Review, Bonn, 1959 Ref. Brandenburg and Koronowski (1969)

Aubert H and Pinta M (1977) Trace Elements in Soils Bd. 7 der Reihe Developments in Soil Science Elsevier, Amsterdam, New York X +396

Baes C F and Sharp R D (1983) A proposal for estimation of soil leaching and leaching constants for use in assessment models J Environ Quality 12 17-28

Baize D and Sterckeman T (2001) Of the necessity of knowledge of the pedo-geochemical background content in the evaluation of contamination of soils by trace elements $\mathrm{Sci}$ Total Environ 264 127-139

Bakkaus E, Collins R N, Morel J L and Googet B (2008) Potential phytoavailability of anthropogenic cobalt in soils as measured by isotope dilution technique Sci Total Environ 406 108-115

Bansal R L, Nayyar V K and Takkar P N (1991) Availability of boron, cobalt and sulfur in ustochrepts J Indian Soc Soil Sci 39 181-182

Beak D G 1, Kirby J K, Hettiarachchi G M, Wendling L A, McLaughlin M J and Khatiwada R (2011) Cobalt distribution and speciation: effect of aging, intermittent submergence, in situ rice roots J Environ Qual 40 679-95

Berrow M L, Burridge J C and Reith J W C (1983) Soil drainage conditions and related plant trace element contents $J$ Sci Food Agric 34 53-54

Bibak A (1994) Cobalt, copper and manganese adsorption by aluminium and iron oxides and humic acid Comm Soil Sci Plant Anal 25 3229-3239

Burns R G (1976) The uptake of cobalt into ferromanganese nodules, soils, and manganese (IV) oxides Geochim Cosmochim Acta 40 95-102

Cappuyns V and Mallaerts T 2014 Background values of cobalt in Flemish and European soils Geol Belg 17 107-114

Collins R N and Kinselaa A S (2010) The aqueous phase speciation and chemistry of cobalt in terrestrial environments Chemosphere 70 763-771

Cornu S, Cattleac J A, Samouëliana A, Laveufa C, Guilhermeade L R G and Albéricf P (2009) Impact of Redox Cycles on
Manganese Iron Cobalt and Lead in Nodules Soil Sci Soc Am J 73 1231-1241

Crerar D A, Cormick R A and Barnes H L (1980) Geochemistry of Manganese: an Overview. In: I Varentsov $\mathrm{M}$ and Grasselly G (Eds.) Geology and Geochemistry of Manganese 1 293-334 Stuttgart FRG

Cyr F, Mehra M C and Mallet V N (1987) Leaching of chemical contaminants from a municipal landfill site Bull Environ Contam Toxicol 38 775-782

Delwiche C C, Johnson C M and Reisenauer H M (1961) Influence of cobalt on nitrogen fixation by medicago Plant Physiol 136 73-8

Dhillon K S and Dhillon S K (2003) Quality of underground water and its contribution towards selenium enrichment of the soil-plant system for a seleniferous region of northwest India $J$ Hydrol 272 120-130

Dilworth M J, Robson A D and Chatel D L (1979) Cobalt and nitrogen fixation in Lupinus angustifolius L II. Nodule formation and function New Pyhtol 83 63-79

Faucon M P, Colinet G, Mahy G, Ngongo L M, Verbruggen N and Meerts P (2009) Soil influence on $\mathrm{Cu}$ and Co uptake and plant size in the cuprophytes Crepidorhopalonperennis and C. tenuis (Scrophulariaceae) in SC Africa Plant Soil 317 201-212

Fleming G A (1983) Aspects of the soil chemistry of cobalt In: SS Augustithis (Ed.) The Significance of Trace Elements in Solving Petrogenetic problems and Controversies 731741 Theuphrastus publications Athens

Friedman H A and Kelmers AD (1988) Investigation of leaching of radionuclides and hazardous materials from low-level wastes at Oak Ridge National Laboratory Washington D C, United States Department of Energy (NTIS/ DE87013363)

Gladstones J S, Loneragan J F and Goodchild N A (1977) Field responses to cobalt and molybdenum by different legume species with inferences on the role of cobalt in legume growth Aus J Agric Res 28619

Grimme H (1968) Die adsorption von $\mathrm{Mn}, \mathrm{Co}, \mathrm{Cu}$ und $\mathrm{Zn}$ durchgoethit au verdünnten losungen $Z$ Pflanzenernähr Bodenkd 121 58-65

Han F X 1, Banin A, Kingery W L and Li Z P (2002) Pathways and kinetics of redistribution of cobalt among solid-phase fractions in arid-zone soils under saturated regime $J$ Environ Sci Health Part A Tox Hazard Subst Environ Eng 37 175-94

Hill A C, Toth S J and Bear F E C (1953) Cobalt status of New Jersey soils and forage plants and factors affecting Co content of the plants Soil Sci 76 273-279 
Jenne E A (1968) Control on $\mathrm{Mn}, \mathrm{Fe}, \mathrm{Co}, \mathrm{Ni}, \mathrm{Cu}$ and $\mathrm{Zn}$ concentration in the soils and water- the significant role of hydrous Mn and Fe oxides. In: Trace organics in water Chapter 21 Adv Chem 73 337-387

Kabir D, Katkar R N and Lakhe S R (2014) Georeferenced Status of Cobalt in Soils of Yavatmal District of Maharashtra. IOSR J Agric Vet Sci (IOSR-JAVS) 7 10-13

Kanwar J S and Randhawa N S (1974) Micronutrient Research in Soils and Plants in India ICAR Tech Bull (Agric) 50 170

Kim J, Gibb H, Herman J, Howe P D and Sheffer M (2006) Cobalt and Inorganic Cobalt Compounds, Issue 69 World Health Organization, 2006 - Medical - 88 pages

King L D (1988) Retention of metals by several soils of the southeastern United States J Environ Quality 17 239-246

Le Rich H H (1973) The distribution of minor elements among the components of a soil developed in loess Geoderma 9 43-57

Li Z (2000) The effects of soil manganese on the availability of soil cobalt for pasture uptake in New Zealand soils. Thesis Doctor of Philosophy, Lincoln University

Li Z, McLaren R G and Metherell A K (1999) The effects of soil manganese status on the bioavailability of soil cobalt for pasture uptake in New Zealand soils Proc N Z Grassld Ass 61 133-137

Li Z, McLaren R G and Metherell A K (2001a) Cobalt and manganese relationships in New Zealand soils NZ J Agric Res 44 191-2001

Li Z, McLaren R G and Metherell A K (2001b) Fractionation of cobalt and manganese in New Zealand soils Aust $J$ Soil Res 39 951-967

Li Z, McLaren R G and Metherell A K (2004) The availability of native and applied soil cobalt to ryegrass in relation to soil cobalt and manganese status and other soil properties N Z J Agric Res 47 33-43

Lindsay W L (1979) Chemical equilibria in soils pp 449 Soil Science Society of America

Mahara Y and Kudo A (1981) Interaction and mobility of cobalt60 between water and sediments in marine environments possible effects by acid rain Water Res 15 413-419

McKenzie R M (1967a) The sorption of cobalt by manganese minerals in soils Aust J Soil Res 5 235-246

McKenzie R M (1967 b) The sorption of cobalt by manganese minerals in soils Aust J Soil Res 8 97-106

McKenzie R M (1970) The reaction of cobalt with manganese oxides minerals Aust J Soil Res 8 97-106

McKenzie R M (1975) An electron microprobe study of the relationships between heavy metals and manganese and iron in soils and ocean floor nodules Aust J Soil Res 13 177-188

McKeague J A and Day J H (1966) Dithionite and oxalateextractable $\mathrm{Fe}$ and $\mathrm{Al}$ as aid in differentiating various classes of soils Can J Soil Sci 46 13-22

McLaren R G, Lawson D M and Swift R S (1986a) The forms of cobalt in some Scottish soils as determined by extraction and isotopic exchange Eur J Soil Sci 37 223-234

McLaren R G, Lawson D M and Swift R S (1986b) Sorption and desorption of cobalt by soils and soil components Eur J Soil Sci 37 413-426

Mitchell R L (1945) Cobalt and nickel in soils and plants Soil Sci 60 63-70

Mitchell R L, Reith J W S and Johnston I M (1957) Trace element uptake in relation to soil content J Sci Food Agric 8 S51S59

Mitchell R L (1960) Trace elements in Scottish soils Proc Nutr Soc 19 148-154

Mitchell R L (1964) Trace elements in soils In FE Bear (Ed.) Chemistry of the soil (2nd ed pp 320-368) New York Reinhold

Morrison R S, Brooks R R, Reeves R D and Malaisse F (1997) Copper and cobalt uptake by metallophytes from Zaier Plant Soil 53 535-539

Murray J W and Dillard J G (1979) Oxidation of cobalt (II) adsorbed on manganese dioxide Geochim Cosmochim Acta 43 781-787

Nadia G and Zaghloul A M (2006) Characteristics of cobalt reactions in some alluvial soils as affected by rate and time of soil incubation J Appl Sci Res 2 192-199

Norrish K (1975) Geochemistry and mineralogy of trace elements In: D.J.D. Nicholas, A.R. Egan (Eds.) Trace Elements in Soil-Plant-Animal Systems. Academic Press, New York 55-81 Academic Press

Oertel A C and Giles J B (1964) A study of some Brigalow soils based on trace element profiles Aust J Soil Res 2 162-172

Piper C S (1950) Soil and Plant Analysis Adelaide, Australia

Randhawa NS and Kanwar JS (1964) Zinc, copper and cobalt status of Punjab soils Soil Sci 98 403-407

Reddy K G and Mehta B V (1961) Investigation on the determination of available cobalt in soils of Kaira district in Gujrat Indian J Agric Sci 31 261-265

Reisenauer H M (1960) Cobalt in nitrogen fixation by a legume Nature 186 375-376

Sanders J R (1983) The effect of pH on the total and free ionic concentration of manganese, zinc and cobalt in soil 
solution J Soil Sci 34 315-323

Schuiling R D, van Enk R J and Bergsma H L T (2003) Natuurlijk voorkomen mobiliteit en industrieel gebruik van "exoten" voorkomend in de Nederlandse bodem (Br, I, Ba, Sb, V, $\mathrm{Sn}, \mathrm{Co}, \mathrm{Mo}, \mathrm{Se})$. Retrieved from http://www.geochem.nl/

Singh S P, Takkar P N, Kaur N P and Nayyar V K (1980) Available boron and cobalt in some selected coarse textured alluvium derived soils of district Jullundur (Punjab) J Res Punjab agric Univ 17 350-353

Smith R M and Martell A E (1976) Critical Stability Constants Inorganic Complexes Vol 4 Plenum Press, New York

Smith R M and Martell A E (1977) Critical Stability Constants Other Stability Constants Other Organic Ligands 3 Plenum Press

Smith I C and Carson B L (1981) Trace metals in the environment Ann Arbor MI Ann Arbor Science Publishers

Stewart A B (1953) Cobalt deficiency in pastures in Great Britain Proc 6th Grassld Congr 1952 I 718-719

Swaine D J (1955) The trace-element content of soils Commmonw Bur Soils Tech Comm 40157

Swaine P J and Mitchell R L (1960) Trace-element distribution in soil profiles $J$ Soil Sci 11 pp 347-368

Takkar P N (1996) Micronutrient research and sustainable agricultural productivity in India J Indian Soc Soil Sci $\mathbf{4 4}$ $562-581$

Takkar P N and Dhillon K S (1984) Selenium toxicity in wheat The Tribune February 151984 Chandigarh India

Takkar P N and Nayyar V K (1979) Iron deficiency affects rice yield in Punjab Indian Fmg 29 9-12

Takkar P N and Nayyar V K (1981) Preliminary field observation of manganese deficiency in wheat and berseem Fertil News $2622-23+33$

Takkar P N, Nayyar V K and Sadana U S (1986) Response of wheat on coarse textured soils to mode and time of manganese application Exp Agric 22 149-152
Takkar P N and Randhawa S S (1990) Specific Geomedical Problems in Asia In: Jul Lag (Ed) Geomedicine CRC Press Boca Raton 245-256

Tashakor M, Yaacob W Z W and Mohamad H (2011) Speciation and availability of $\mathrm{Cr}, \mathrm{Ni}$ and $\mathrm{Co}$ in serpentine soils of Ranau Sabah Am J Geosci 2 4-9

Taylor R M (1968) The association of manganese and cobalt in soils- Future observations $J$ Soil Sci 19 77-80

Taylor R M and McKenzie R M (1966) The association of trace elements with manganese minerals in Australian soils Aust J Soil Res 4 29-39

Tiller K G and Hodgson J F (1962) The specific sorption of cobalt and zinc by layer silicates Clays Clay Miner 9 393-419

Ure A M and Berrow M L 1982 The chemical constituent of soils In: H J M Bowen (Editor) Environ ChemR SocChem Burlington House London pp 94-202

Uren N C (2013) Cobalt and Manganese In: Brian J Alloway (Ed) Heavy Metals in Soils Trace Metals and Metalloids in Soils and their Bioavailability Environ Pollut 22 335366 Springer

Walkley A (1947) A critical examination of a rapid method for determining organic carbon in soils: Effect of variations in digestion conditions and of inorganic soil constituents Soil Sci 63 251-263

Wendling L A, Kirby J K and McLaughlin M J (2007) Cobalt speciation and exchangeability in soils In: Yongguan Zhu, Nicholas W. Lepp and R. Naidu (Ed), Biogeochemistry of Trace Elements: Environmental Protection, Remediation and Human Health Proc 9th Int Conf Biogeochem Trace Elements (9th ICOBTE) Beijing China, (1001-1002). 1519

Wendling L A 1, Ma Y, Kirby J K and McLaughlin M J (2009) A predictive model of the effects of aging on cobalt fate and behavior in soil Environ Sci Technol 43 135-41. 